Aus der Abteilung Pädiatrie III

mit Schwerpunkt Pädiatrische Kardiologie und Intensivmedizin

(Prof. Dr. med. Th. Paul)

im Zentrum Kinderheilkunde und Jugendmedizin

der Medizinischen Fakultät der Universität Göttingen

Immunhistochemische Charakterisierung von neugebildeten Geweben im Bereich von interventionell eingesetzten Okkludern

für den Verschluss von angeborenen Septumdefekten des Herzens

INAUGURAL - DISSERTATION

zur Erlangung des Doktorgrades

der Medizinischen Fakultät der

Georg-August-Universität zu Göttingen

vorgelegt von Rudi R. Foth

aus Bielefeld

Göttingen 2009 
Dekan: Prof. Dr. med. C. Frömmel

I. Berichterstatter: PD Dr. med. M. Sigler

II. Berichterstatter/in:

III. Berichterstatter/in:

Tag der mündlichen Prüfung: 
Inhaltsverzeichnis

Seite

Vorbemerkung

1 Einleitung 4

1.1 Entwicklung der interventionellen Kinderkardiologie 4

1.2 Angeborene Herzfehler 5

1.2.1 Vorhofseptumdefekt 5

1.2.2 Ventrikelseptumdefekt 6

1.2.3 Komplexe Herzfehler 6

1.3 Implantate $\quad 7$

$\begin{array}{ll}\text { 1.3.1 Amplatzer-Verschlusssysteme } & 7\end{array}$

1.3.2 Cardioseal- und Starflex-Verschlusssysteme $\quad 7$

1.4 Biokompatibilität kardiovaskulärer Implantate 8

2 Material und Methoden $\quad 8$

2.1 Explantate $\quad 8$

2.2 Aufarbeitung der kardiovaskulären Implantate nach Explantation 9

3 Darstellung und Diskussion der Ergebnisse 10

$\begin{array}{ll}3.1 \text { Neoendothel } & 10\end{array}$

3.2 Einwachsen der Implantate und Zelldifferenzierung der 11 neugebildeten Gewebe

3.3 Toxische Reaktionen auf das Fremdmaterial 13

$\begin{array}{ll}3.4 \text { Entzündungsreaktionen } & 13\end{array}$

4 Zusammenfassung 14

$\begin{array}{ll}5 \text { Literaturverzeichnis } & 15\end{array}$ 


\section{Vorbemerkung}

Diese kumulative Schrift gründet sich auf die nachfolgende Originalarbeit in Erstautorenschaft:

Foth R, Quentin T, Michel-Behnke I, Vogt M, Kriebel T, Kreischer A, Ruschewski W, Paul T, Sigler M (2009): Immunohistochemical characterization of neotissues and tissue reactions to septal defectocclusion devices. Circ Cardiovasc Intervent 2: 90-96

sowie auf die nachfolgenden Originalarbeiten in Co-Autorenschaft:

Quentin T, Poppe A, Bär K, Sigler A, Foth R, Michel-Behnke I, Paul T, Sigler M (2009): A novel method for processing of resin-embedded specimens with metal implants for immunohistochemical labelling. Acta Histochem 111: 538-542

Vogt MO, Kühn A, Hörer J, Schreiber C, Schneider H, Foth R, Eicken A, Hess J, Sigler M (2009): Clinical, echocardiographic and histopathologic findings in nine patients with surgically explanted ASD/PFO devices: Do we know enough about the healing process in humans? Int $\mathrm{J}$ Cardiol - im Druck

Die drei genannten Arbeiten sind der Kumulativschrift angefügt. 


\section{Einleitung}

\subsection{Entwicklung der interventionellen Kinderkardiologie}

Durch große Fortschritte in den vergangenen Jahrzehnten im Bezug auf das Wissen um spezifische hämodynamische Verhältnisse, die Weiterentwicklung apparativer diagnostischer Verfahren sowie die Optimierung von chirurgischen und interventionellen Behandlungsmethoden kann heute kardiologischen Patienten eine Vielzahl kausaler und damit kurativer Behandlungskonzepte angeboten werden. Dies gilt nicht nur für erwachsene Patienten, sondern auch für Kinder mit zum Teil komplexen angeborenen Herzfehlern.

Forssmann führte im Jahr 1929 im Selbstversuch eine Rechtsherzkatheterisierung über einen peripheren Zugang am rechten Arm durch (Forssmann 1929), bevor Rechtsherzkatheteruntersuchungen im Laufe der 40er Jahre des vergangenen Jahrhunderts Teil der klinischen Routine wurden. 1947 berichteten Dexter und Mitarbeiter über Rechtsherzkatheteruntersuchungen bei Kindern mit angeborenen Herzfehlern (Dexter et al. 1947). Zunächst wurden Herzkatheteruntersuchungen ausschließlich als diagnostische Maßnahme durchgeführt.

Einen Meilenstein in der Behandlung angeborener Herzfehler stellte der erstmalige chirurgische Verschluss eines Vorhofseptumdefektes unter dem Einsatz einer HerzLungen-Maschine im Jahre 1954 durch Gibbon dar (Gibbon 1954). Zunächst blieb der Chirurgie die Möglichkeit vorbehalten, Patienten mit einem angeborenen Herzfehler eine kurative Therapie anzubieten. In den Folgejahren entwickelte sich ein zunehmendes Bestreben, interventionelle Therapieverfahren zu entwickeln. Dotter und Judkins berichteten erstmals 1964 über die perkutane transluminale Rekanalisation von Stenosen bei arteriosklerotisch veränderten Gefäßen (Dotter und Judkins 1964).

Ihnen folgten zwei Jahre später Rashkind und Miller mit dem Bericht über die ersten erfolgreichen nicht-chirurgischen Atrioseptostomien zur Vergrößerung der atrialen Shuntkommunikation bei Neugeborenen mit Transposition der großen Arterien (Rashkind und Miller 1966). Das Rashkindmanöver ist auch heute noch ein Standardverfahren in der Akutbehandlung dieser Kinder.

Rashkind war es ebenfalls, der 1979 erstmals den katheterinterventionellen Verschluss des Ductus arteriosus bei einem Säugling beschrieb (Rashkind und 
Cuaso 1979). Zwölf Jahre zuvor hatte bereits Porstmann den ersten interventionellen Ductus-Verschluss bei einem erwachsenen Patienten durchführen können (Porstmann et al. 1967).

King und Mitarbeitern gelang es 1976 erstmals, einen Vorhofseptumdefekt vom Sekundumtyp bei einer 17-jährigen Patientin interventionell zu verschließen (King et al. 1976). Sigwart berichtete 1987 über die ersten Stentimplantationen bei Erwachsenen (Sigwart et al. 1987) sowie vier Jahre später O'Laughlin bei einem pädiatrischen Patienten (O'Laughlin et al. 1991).

\subsection{Angeborene Herzfehler}

$\mathrm{Zu}$ der Gruppe der angeborenen Herzfehler gehören alle angeborenen Fehlbildungen des Herzens und der herznahen Blutgefäße. Von 1000 Lebendgeborenen sind 12 Kinder betroffen (Clark 1995).

\subsubsection{Vorhofseptumdefekt}

Ein Vorhofseptumdefekt resultiert embryologisch aus einer Störung der Septierung des initial singulären Vorhofes. Der Vorhofseptumdefekt vom Primumtyp (ASD I) befindet sich kaudal der Fossa ovalis. Dagegen befindet sich der Vorhofseptumdefekt vom Sekundumtyp (ASD II) in der Regel zentral im Bereich der Fossa ovalis.

Vorhofseptumdefekte führen zur Entwicklung eines Links-Rechts-Shuntes mit Volumenbelastung des rechten Herzens. Der dadurch vermehrte Blutfluss in der Lungenstrombahn führt zu langsam fortschreitenden Gefäßveränderungen mit Mediahypertrophie und Intimaproliferation. Schließlich kommt es durch eine konsekutive Lumeneinengung in den Lungengefäßen zu einem Anstieg des Lungengefäßwiderstandes und als Spätfolge zur so genannten EisenmengerReaktion mit Shunt-Umkehr und Ausbildung einer Zyanose durch den resultierenden Rechts-Links-Shunt. 


\subsubsection{Ventrikelseptumdefekt}

Die angeborenen Ventrikelseptumdefekte (VSD) haben ebenfalls ihren Ursprung in der embryonalen Entwicklungsphase. Die Ventrikelseptumdefekte lassen sich anhand ihrer anatomischen Lokalisation in 4 Typen einteilen (McDaniel und Gutgesell 2000):

I. Perimembranöser Typ (80 \% der VSD). Er reicht häufig in die muskulären Anteile sowie in die Inlet- oder Outlet-Bereiche hinein.

II. Outlet-Typ (5 - 7 \% der VSD). Er befindet sich unterhalb der Pulmonalklappe.

III. Inlet-Typ (5 - $8 \%$ der VSD). Er liegt posterior und inferior der perimembranösen Defekte.

IV. Muskulärer Typ (5 - 20 \% der VSD) mit zentralen, apikalen, marginalen und multiplen (swiss-cheese) VSD.

Bedingt durch den entstehenden Links-Rechts-Shunt entwickelt sich zunächst eine Volumenbelastung für die linke Herzkammer. Schließlich ist auch bei Ventrikelseptumdefekten wie bei Vorhofseptumdefekten die Ausbildung einer Eisenmenger-Reaktion durch einen ansteigenden pulmonalen Widerstand mit anschließender Shunt-Umkehr möglich.

\subsubsection{Komplexe Herzfehler}

Bei Patienten mit komplexen kongenitalen Herzfehlbildungen ist häufig nur ein ausreichend groß entwickelter Ventrikel vorhanden. Die operative Palliation bei diesen Patienten wird mit dem Ziel der Trennung von Körper- und Lungenkreislauf durchgeführt. In mehreren Operationsschritten erfolgt die Umleitung des Blutrückflusses aus dem Körper direkt in die Lunge. Häufig wird bei der abschließenden modifizierten Fontan-Operation eine Fenestration als Überlaufventil aus dem systemvenösen Rückfluss im Bereich des rechten Vorhofes belassen. Dieser Kurzschluss wird in der Regel nach einigen Monaten mittels Okkluder interventionell verschlossen. 


\subsection{Implantate}

In der vorliegenden Arbeit wurden Verschlusssysteme vom Typ Amplatzer (AGA Medical Inc., Golden Valley, MN, USA) und Cardioseal bzw. Starflex (NMT Medical Inc., Boston, MA, USA) untersucht. Beide zählen zu den aktuell am häufigsten verwendeten Systemen.

\subsubsection{Amplatzer-Verschlusssysteme}

Der Amplatzer-Septal-Okkluder (AGA Medical Inc., Golden Valley, MN, USA) ist ein selbstexpandierendes und -zentrierendes Doppelschirmchen aus einem Nitinoldrahtgeflecht, bei dem beide Schirmanteile über einen zentralen Anteil, dessen Durchmesser der Defektgröße entspricht, verbunden sind. Innerhalb des Okkluders sind Polyesterfasern eingelagert, die den Verschluss des Defektes durch Fibrinkondensation begünstigen.

Nitinol ist eine metallische Legierung (55\% Nickel und 45\% Titan). Es wird wegen seiner Formgedächtniseigenschaft bevorzugt als Material für katheterinterventionell applizierte Implantate verwendet.
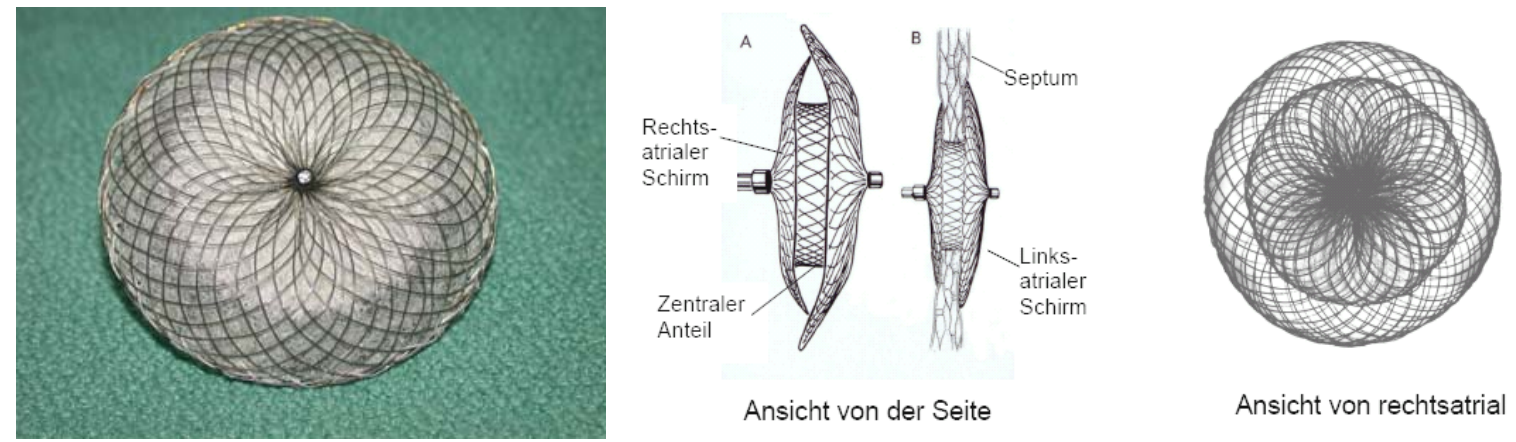

Linke Abbildung: Linksatriale Ansicht eines Amplatzer-ASD-Okkluders. Rechte Abbildung: Schematische Darstellung eines Amplatzer-ASD-Okkluders mit intrakardialer Position in der seitlichen Ansicht sowie in der rechtsatrialen Ansicht.

\subsubsection{Cardioseal- und Starflex-Verschlusssysteme}

Die Verschlusssysteme Cardioseal und Starflex (NMT Medical INC, Boston, MA, USA) bestehen aus einem Doppelschirmsystem, bei denen die Arme aus korrosionsbeständigem, medizinischen Edelstahl (MP35e) bestehen und mit Polyester-Membranen (Dacron) bespannt sind. Das Starflex-Verschlusssystem 
enthält als modifizierte Weiterentwicklung zum Cardioseal-System selbstzentrierende flexible Federn aus Nitinol.

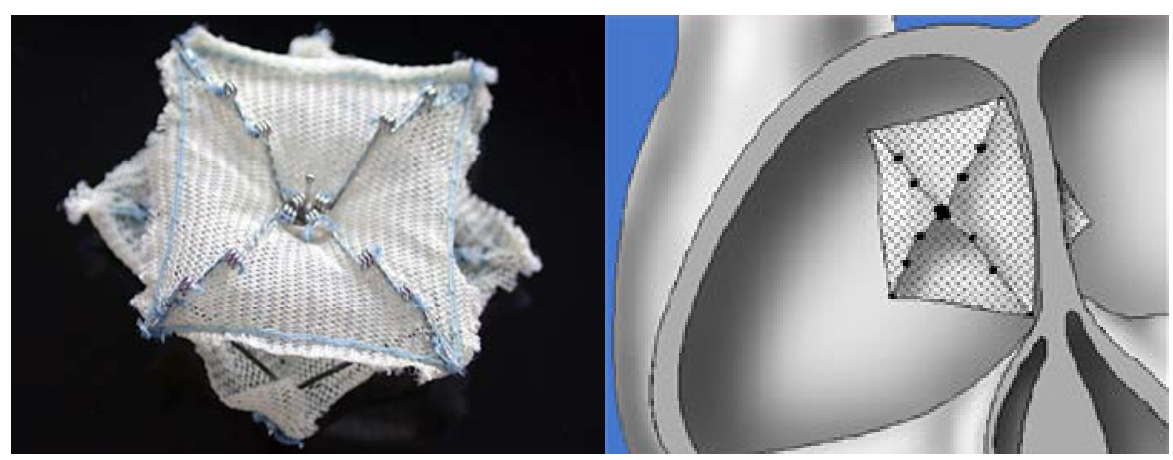

Linke Abbildung: Starflex-ASD-Okkluder, Blick auf den rechtsatrialen Schirm. Rechte Abbildung: Schematische Darstellung eines Cardioseal-Okkluders in intrakardialer Position.

\subsection{Biokompatibilität kardiovaskulärer Implantate}

Wie erwähnt stellen Verfahren der interventionellen Kardiologie häufig Alternativen zu operativen Verfahren dar. Zunächst standen die technische Ausführung und die Sicherheit implantierter Systeme im Fokus der wissenschaftlichen Bemühungen. Unter der Annahme einer möglichst lebenslangen Verweildauer des Implantates im Körper des Patienten hat sich in den letzten Jahren nun ein zunehmendes Interesse an Informationen zum Einwachsen der Implantate unter dem Aspekt der Biokompatibilität entwickelt. Neben tierexperimentellen Studien (Sideris et al. 1992, Kuhn et al. 1996, Sharafuddin et al. 1997, Sigler et al. 2000, Sigler et al. 2005, Sigler und Jux 2007) gibt es bisher nur wenige Veröffentlichungen über das Einwachsen der Implantate im menschlichen Organismus (Kreutzer et al. 2001, Ries et al. 2003, Sigler et al. 2006, Ahn et al. 2009).

\section{Material und Methoden}

\subsection{Explantate}

In einer von uns durchgeführten Studie wurden 10 operativ entfernte SeptumdefektOkkluder aus 5 verschiedenen Zentren aufgearbeitet. Von diesen 10 Implantaten waren 7 ASD-Okkluder, die sich wiederum in 4 Amplatzer-ASD-Okkluder, 2 Cardioseal-ASD-Okkluder und 1 ASD-Starflex-Okkluder unterteilten. Des Weiteren waren 2 Amplatzer-VSD-Okkluder in Ventrikelseptumdefekte sowie ein Amplatzer- 
VSD-Okkluder zum Verschluss einer Fenestration nach Anlage einer totalen kavopulmonalen Anastomose bei einem Kind mit einem komplexen Herzfehler eingesetzt worden. Die operative Entfernung war aus folgenden Gründen erfolgt: residuelle Shuntflüsse $(n=3)$, Dislokationen der Implantate $(n=4)$, Beeinträchtigungen der Klappenfunktion durch das Implantat selbst $(n=1)$, atypische Konfiguration des Implantates $(n=1)$ und wiederkehrende neurologische Ereignisse $(n=1)$. Die Implantationsdauer betrug zwischen 5 Tagen und 48 Monaten.

\subsection{Aufarbeitung der kardiovaskulären Implantate nach Explantation}

Alle untersuchten Präparate wurden nach Explantation in Formalin fixiert. Da das Standardverfahren zur Aufarbeitung von Gewebeproben für die histopathologische Begutachtung (Paraffineinbettung, Dünnschnitttechnik) aufgrund der Metall- und Kunststoffanteile der Implantate nicht angewandt werden konnte, erfolgte die Einbettung der Implantate mit umgebenden Gewebeanteilen in das Kunstharz Methylmethacrylat (Technovit 9100, Kulzer \& Co, Wehrheim, Germany). Diese Methode wurde bereits von Donath und Breuner beschrieben (Donath und Breuner 1982). Nachdem der Kunstharzblock ausgehärtet war, wurde er mit Silikonkleber (Elastosil E41, Wacker Chemie GmbH, München, Germany) auf einem Glasobjektträger geklebt. Mit Hilfe einer Diamantsäge (300 CP, Exakt GmbH, Norderstedt, Germany) und eines Rotations-Schleifautomaten (400 CS, Exakt $\mathrm{GmbH}$, Norderstedt, Germany) wurden dann Präparate mit einer Dicke von 5 - 30 $\mu \mathrm{m}$ für die anschließenden immunhistochemischen Färbungen hergestellt.

Die Verwendung dieses speziellen Silikonklebers ist ein in unserem Labor entwickeltes Verfahren, welches es erlaubt, das Methylmethacrylat für immunhistochemische Färbungen wieder aus dem Präparat herauszulösen (Deplastifikation), ohne dass sich das Präparat während der Inkubation in den verschiedenen Lösungsmitteln vom Objektträger wieder löst (Quentin et al. 2009). 


\section{Darstellung und Diskussion der Ergebnisse}

Die bisherigen Untersuchungen der Biokompatibilität von explantierten septalen Verschlusssystemen beschränkten sich auf die morphologische Beschreibung der Zellen im neuformierten Gewebe (Sigler et al. 2000, Kreutzer et al. 2001, Jux et al. 2006). Unsere Arbeitsgruppe veröffentlicht nun erstmals Ergebnisse von immunhistochemischen Untersuchungen an einer humanen Serie von explantierten Okkludern (Foth et al. 2009).

\subsection{Neoendothel}

Die Ausbildung von Endothel im Bereich von kardiovaskulären Implantaten ist von besonderer klinischer Bedeutung. Eine unvollständige Endothelialisierung eines Implantates wird mit einem signifikanten Risiko für die Entstehung oberflächlicher Thromben in Verbindung gebracht (Anzai et al. 2004, Krumsdorf et al. 2004, Vogt et al. 2009). Daher ist die Behandlung der Patienten nach der Implantation eines Okkluders mit einem Thrombozytenaggregationshemmer ein gängiges Verfahren zur Vermeidung oberflächlicher Thromben. Die Behandlung erfolgt für den Zeitraum von 6 Monaten, in dem üblicherweise die vollständige Endothelialisierung zu erwarten ist. Mittels Elektronenmikroskopie konnte bereits unmittelbar nach Implantation die Ausbildung einer oberflächlichen Schicht mit anschließender Ansiedlung einer einlagigen Zellschicht an der Oberfläche der Implantate nach einer Implantationsdauer von 3 Monaten gezeigt werden (Sigler et al. 2005, Sigler und Jux 2007). In unsere Serie war bereits nach 5 Tagen Implantationsdauer makroskopisch an der Oberfläche eine durchgehende dünne und blass-gräuliche Gewebeschicht vorhanden. Mittels immunhistochemischer Färbungen konnten wir zeigen, dass diese aus Fibrin und Blutzellen bestand.

Die Implantate mit einer Implantationsdauer von länger als 10 Wochen zeigten makroskopisch an der Oberfläche eine glänzende weißliche Gewebeschicht. Diese Gewebeschicht war in allen Implantaten mit einer Implantationsdauer von länger als 10 Wochen vollständig über das gesamte Implantat ausgebildet. Immunhistochemisch konnten die oberflächlichen Zellen dieser Gewebeschicht als Endothelzellen identifiziert werden. Sie färbten positiv für den spezifischen Endothelzellmarker von-Willebrand-Faktor. Mit diesen Färbungen konnten wir somit 
funktionell kompetente Endothelzellen als oberste Zellschicht im neuformierten Gewebe auf explantierten Okkludern nachweisen.

\subsection{Einwachsen der Implantate und Zelldifferenzierung der neugebildeten Gewebe}

Direkt nach der Implantation eines septalen Verschlusssystemes bildet sich Fibrin und thrombotisches Material im Inneren des Implantates um die Metall- und Kunststoffanteile herum (Sigler und Jux 2007). Dieser Vorgang ist im Gegensatz zur appositionellen Thrombenbildung auf der Implantatoberfläche erwünscht, denn er führt zur Hämostase und zu dem dadurch bedingten Verschluss des Defektes.

Mit unseren Beobachtungen war es uns nun möglich, den zeitlichen Ablauf der Thrombusorganisation im Inneren des Implantates einzuordnen. Nach einer Implantationsdauer von 5 Tagen fanden sich in unmittelbarer Nähe zum Fremdmaterial ausschließlich Fibrin und Blutzellen. Nach einer Implantationsdauer von 10 Wochen lag bereits eine fortgeschrittene und nach 24 Monaten eine abgeschlossene zelluläre Organisation des thrombotischen Materials vor.

Das so neuformierte Gewebe bestand aus einer Extrazellulärmatrix, die überwiegend Proteoglykane, Kollagenfasern und elastische Fasern enthielt, wie wir anhand von histologischen Färbungen (Movat Pentachrom und Pikrosiriusrot) nachweisen konnten. Darin eingebettet befanden sich fibroblastenähnliche Zellen, welche überwiegend parallel zur Oberfläche angeordnet waren. Diese Gewebeschicht wurde als Pseudointima bezeichnet. Im Gegensatz zu diesen gleichmäßig ausgerichteten Zellen in der Pseudointima hatten die Zellen im Inneren der Implantate kein einheitliches Anordnungsmuster. Zudem waren signifikant mehr Kapillaren und kleine Gefäße im Vergleich zur Pseudointima vorhanden. Kreutzer et al. beschreiben diesen inneren Bereich des Implantates als „areolar fibrous tissue“ (Kreutzer et al. 2001).

Die Herkunft der Zellen in einem solchen neugebildeten Gewebe ist bislang ungeklärt. Es wird vermutet, dass sie entweder aus der Vermehrung lokaler Fibroblasten stammen oder aus im Blut zirkulierenden Zellen. Bei diesen zirkulierenden Zellen kann es sich um Fibrozyten (Bellini und Mattoli 2007, Varcoe et al. 2006) oder Endothelvorläuferzellen handeln (Kawai-Kowase und Owens 2007).

Zur Differenzierung der vorhandenen Zellen im neuformierten Gewebe verwendeten wir eine Reihe von Markern, welche zur Differenzierung von Myofibroblasten oder 
glatten Muskelzellen eingesetzt werden. Hierzu zählen Antikörper gegen die beiden Intermediärfilamente Vimentin und Desmin sowie gegen Proteine des kontraktilen Apparates der Zelle wie Smooth Muscle Actin (SMA), Smooth Muscle Myosin (SMM) und h-Caldesmon (Hinz 2007).

Vimentin ist ein Marker für Zellen mesenchymaler Herkunft. Die Zellen des Neogewebes waren durchgehend positiv für Vimentin angefärbt. Bereits nach einer Implantationszeit von nur 5 Tagen ließen sich Vimentin-positive Zellen im Inneren des Implantates nachweisen.

SMA ist eine Aktin-Isoform, welche man in den kontraktilen Fasern von glatten Muskelzellen oder Myofibroblasten findet. Zellen mit positiver Anfärbung für SMA waren nach einer Implantationszeit von 10 Wochen in allen angefärbten Implantaten in der Pseudointima und im Inneren der Implantate zu finden.

Neben SMA verwendeten wir SMM als weiteren Marker für den Differenzierungsgrad des kontraktilen Apparates der Zellen. SMM ist eine spezielle Isoform des Myosins, welches in den glatten Muskelzellen der Gefäßmedia vorkommt (Owens et al. 2004). In der Pseudointima waren Zellen mit Antikörpern gegen SMM nach einer Implantationszeit von 10 Monaten vorhanden, im Inneren sahen wir positive Zellen für SMM bereits nach einer Dauer von 10 Wochen.

$\mathrm{H}$-Caldesmon wird in glatten Muskelzellen exprimiert und ist an der Regulation der Kontraktion beteiligt, indem es an Aktin und Myosin bindet (McMartin et al. 2003). Positive Zellen für h-Caldesmon waren nur in einem Implantat mit einer längeren Implantationsdauer (15 Monate) sowohl in der Pseudointima als auch im Inneren des Implantates zu finden.

Desmin ist wie Vimentin ein Intermediärfilament. Es ist wird in Skelettmuskelzellen und Herzmuskelzellen exprimiert und ist in unterschiedlichem Ausmaß auch in glatten Muskelzellen der Gefäße zu finden (Tang 2008). Wie im Falle von hCaldesmon waren Desmin-positive Zellen nur in Implantaten mit einer längeren Implantationszeit von 10 bzw. 48 Monaten nachweisbar.

Die oben vorgestellten Marker werden auch in der Literatur zur Beschreibung des Reifungszustandes glatter Muskelzellen verwendet (Frid et al. 1992, Hungerford und Little 1999, Hall et al. 2000).

Zellen, welche nur mit Vimentin, SMA und SMM positiv angefärbt waren, zeigten ein Färbemuster, wie man es bei unreifen glatten Muskelzellen findet. Die zusätzliche Expression von Desmin und $\mathrm{h}$-Caldesmon beschreibt hingegen einen reifen 
Phänotyp der glatten Muskelzellen (Owens et al. 2004, Zalewski et al. 2002, Patel et al. 2000).

Die Tatsache, dass nach längerer Implantationszeit mit Desmin und h-Caldesmon auch Marker mit einem höheren Differenzierungsgrad in dem Neogewebe exprimiert werden, kann als Ausdruck eines langsamen Ausreifens der neugebildeten Zellen interpretiert werden.

\subsection{Toxische Reaktionen auf das Fremdmaterial}

Es ist bekannt, dass es nach Implantation von metallhaltigen kardiovaskulären Implantaten zu einer lokalen und systemischen Elution von Metallionen kommt (Ries et al. 2003, Burian et al. 2006). In den von uns untersuchten Explantaten zeigten die Zellen in unmittelbarer Nähe zu den Metallstreben unabhängig von der Implantationszeit positive Färbungen für Vimentin, SMA und SMM. Wir fanden somit keinen Hinweis für toxische Reaktionen auf Metallionen im Sinne eines abweichenden Differenzierungsgrades dieser Zellen.

\subsection{Entzündungsreaktionen}

Das Auftreten mehrkerniger Fremdköperriesenzellen in unmittelbarer Nähe zu den Dacronfasern ist bereits mehrfach in Implantaten beobachtet worden (Kreutzer et al. 2001, Ahn et al. 2009). Wir konnten diese Zellen spezifisch mit dem Makrophagenmarker CD 68 anfärben und betrachten das Auftreten dieser Zellen als Reaktion der angeborenen Immunantwort.

Vereinzelte lymphozytäre Infiltrate sind bereits mehrfach im neuformierten Gewebe im Bereich kardiovaskulärer Implantate beschrieben worden, allerdings ohne weitergehende Differenzierung (Kreutzer et al. 2001, Sigler und Jux 2007). Mittels Antikörper gegen CD 3 und CD 79 konnten wir diese Zellen spezifisch als B- und TLymphozyten differenzieren. Somit finden wir neben der angeborenen Immunantwort auch Hinweise auf eine adaptive Reaktion des Immunsystems. 


\section{Zusammenfassung}

Dies ist die erste immunhistochemische Untersuchung an einer Serie von explantierten septalen Verschlusssystemen. Es gelang uns die spezifische immunhistochemische Identifizierung von Endothel in allen untersuchten ASD- und VSD-Okkludern bei einer Implantationsdauer von über 10 Wochen.

Im Rahmen der zellulären Organisation des initial thrombotischen Gewebes fanden wir innerhalb der Okkluder fibromuskuläre Zellen. Zur immunhistochemischen Untersuchung dieser Zellen wurden Marker verwendet, welche zur Beschreibung des Reifungsgrades glatter Muskelzellen dienen. Hierbei zeigte sich, dass diese Zellen in der Mehrzahl einen Phänotyp hatten, welcher dem unreifer glatter Muskelzellen ähnelte. In Implantaten mit einer längeren Implantationsdauer konnten hingegen auch Marker gefunden werden, welche nur in reifen glatten Muskelzellen exprimiert werden. Dies kann als Hinweis für ein langsames Ausreifen dieser Zellen interpretiert werden. Bei den Untersuchungen zur Entzündungsreaktion zeigte sich, dass es sowohl zu einer angeborenen als auch zu einer adaptiven Antwort des Immunsystems kommt.

Basierend auf den Ergebnissen der durchgeführten immunhistochemischen Charakterisierung von Gewebereaktionen auf kardiovaskuläre Implantate sollen in Zukunft weitergehende Untersuchungen durchgeführt werden. Unter anderem sollen mRNA-Expressionsprofile erstellt werden. Ziel ist dabei die Identifikation von weiteren Faktoren, welche für Gewebeorganisation und Zelldifferenzierung verantwortlich sind, um möglicherweise in Zukunft Reaktionen des Organismus auf Implantate im kardiovaskulären System gezielt therapeutisch beeinflussen und optimieren zu können. 


\section{Literaturverzeichnis}

Ahn E, Luk A, Mezody M, Horlick E, Ross H, Butany J (2009): Early morphological changes of an Amplatzer Septal Occluder explanted at heart transplant. Cardiovasc Pathol 18: 57-60

Anzai H, Child J, Natterson B, Krivokapich J, Fishbein MC, Chan VK, Tobis JM (2004): Incidence of thrombus formation on the CardioSEAL and the Amplatzer interatrial closure devices. Am J Cardiol 93: 426-431

Bellini A, Mattoli S (2007): The role of the fibrocyte, a bone marrow-derived mesenchymal progenitor, in reactive and reparative fibroses. Lab Invest $\underline{87}$ : 858-870

Burian M, Neumann T, Weber M, Brandt R, Geisslinger G, Mitrovic V, Hamm C (2006): Nickel release, a possible indicator for the duration of antiplatelet treatment, from a nickel cardiac device in vivo: a study in patients with atrial septal defects implanted with an Amplatzer occluder. Int J Clin Pharmacol Ther 44: 107-112

Clark EB: Morphogenesis, growth, and biomechanics: mechanisms of cardiovascular development; in: Heart disease in infants, children, and adolescents; hrsg. v. Moss AJ, Adams FH; Williams and Wilkens, Baltimore 1995, 1-16

Dexter L, Haynes FW, Burwell CS, Eppinger EC, Seibel RE, Evans JM (1947): Studies of congenital heart disease. I. Technique of venous catheterization as a diagnostic procedure. J Clin Invest 26: 547-553

Donath K, Breuner G (1982): A method for the study of undecalcified bones and teeth with attached soft tissues. The Säge-Schliff (sawing and grinding) technique. J Oral Pathol 11: 318-326

Dotter CT, Judkins MP (1964): Transluminal treatment of arteriosclerotic obstruction. Description of a new technic and a preliminary report of its application. Circulation $\underline{30}$ : 654-670 
Forssmann W (1929): Über die Sondierung des rechten Herzens. Klin Wochenschr $\underline{8}$ : 2085

Foth R, Quentin T, Michel-Behnke I, Vogt MO, Kriebel T, Kreischer A, Ruschewski W, Paul T, Sigler M (2009): Immunohistochemical characterization of neotissues and tissue reactions to septal defect-occlusion devices. Circ Cardiovasc Intervent 2: 9096

Frid MG, Shekhonin BV, Koteliansky VE, Glukhova MA (1992): Phenotypic changes of human smooth muscle cells during development: late expression of heavy caldesmon and calponin. Dev Biol 153: 185-193

Gibbon JH, Jr. (1954): Application of a mechanical heart and lung apparatus to cardiac surgery. Minn Med 37: 171-185

Hall SM, Hislop AA, Pierce CM, Haworth SG (2000): Prenatal origins of human intrapulmonary arteries: formation and smooth muscle maturation. Am J Respir Cell Mol Biol 23: 194-203

Hinz B (2007): Formation and function of the myofibroblast during tissue repair. J Invest Dermatol 127: 526-537

Hungerford JE, Little CD (1999): Developmental biology of the vascular smooth muscle cell: building a multilayered vessel wall. J Vasc Res $\underline{36}$ : 2-27

Jux C, Bertram H, Wohlsein P, Bruegmann M, Paul T (2006): Interventional atrial septal defect closure using a totally bioresorbable occluder matrix: development and preclinical evaluation of the BioSTAR device. J Am Coll Cardiol 48: 161-169

Kawai-Kowase K, Owens GK (2007): Multiple repressor pathways contribute to phenotypic switching of vascular smooth muscle cells. Am J Physiol Cell Physiol 292: C59-C69 
King TD, Thompson SL, Steiner C, Mills NL (1976): Secundum atrial septal defect. Nonoperative closure during cardiac catheterization. JAMA 235: 2506-2509

Kreutzer J, Ryan CA, Gauvreau K, Van Praagh R, Anderson JM, Jenkins KJ (2001): Healing response to the Clamshell device for closure of intracardiac defects in humans. Catheter Cardiovasc Interv 54: 101-111

Krumsdorf U, Ostermayer S, Billinger K, Trepels T, Zadan E, Horvath K, Sievert H (2004): Incidence and clinical course of thrombus formation on atrial septal defect and patient foramen ovale closure devices in 1,000 consecutive patients. J Am Coll Cardiol 43: 302-309

Kuhn MA, Latson LA, Cheatham JP, McManus B, Anderson JM, Kilzer KL, Furst J (1996): Biological response to Bard Clamshell Septal Occluders in the canine heart. Circulation 93: 1459-1463

McDaniel NL, Gutgesell HP: Ventricular septal defect; in: Heart disease in infants, children, and adolescents, including the fetus and young adult; hrsg. v. Moss AJ, Adams FH; Williams and Wilkens, Baltimore 2000, 636-651

McMartin GA, Wirch E, Abraham N, Kargacin GJ (2003): Postnatal changes in caldesmon expression and localization in cardiac myocytes. J Anat 203: 369-377

O'Laughlin MP, Perry SB, Lock JE, Mullins CE (1991): Use of endovascular stents in congenital heart disease. Circulation 83: 1923-1939

Owens GK, Kumar MS, Wamhoff BR (2004): Molecular regulation of vascular smooth muscle cell differentiation in development and disease. Physiol Rev 84: 767-801

Patel S, Shi Y, Niculescu R, Chung EH, Martin JL, Zalewski A (2000): Characteristics of coronary smooth muscle cells and adventitial fibroblasts. Circulation 101: 524-532

Porstmann W, Wierny L, Warnke H (1967): Der Verschluss des Ductus arteriosus persistens ohne Thorakotomie. Thoraxchir Vask Chir 15: 199-203 
Quentin T, Poppe A, Bär K., Sigler A, Foth R, Michel-Behnke I, Paul T, Sigler M (2009): A novel method for processing resin-embedded specimens with metal implants for immunohistochemical labelling. Acta Histochem 111: 538-542

Rashkind WJ, Cuaso CC (1979): Transcatheter closure of patent ductus arteriosus. Successful use in a 3.5 kilogram infant. Pediatr Cardiol 1: 3-7

Rashkind WJ, Miller WW (1966): Creation of an atrial septal defect without thoracotomy: palliative approach to complete transposition of the great arteries. JAMA 196: 991-992

Ries MW, Kampmann C, Rupprecht HJ, Hintereder G, Hafner G, Meyer J (2003): Nickel release after implantation of the Amplatzer occluder. Am Heart J 145: 737-741

Sharafuddin MJ, Gu X, Titus JL, Urness M, Cervera-Ceballos JJ, Amplatz K (1997): Transvenous closure of secundum atrial septal defects: preliminary results with a new self-expanding nitinol prosthesis in a swine model. Circulation 95: 2162-2168

Sideris EB, Sideris SE, Fowlkes JP, Ehly RL, Smith JE, Gulde RE(1990): Transvenous atrial septal defect: Occlusion in piglets with a "buttoned" double-disk device. Circulation 81: 312-318

Sigler M, Jux C (2007): Biocompatibility of septal defect closure devices. Heart $\underline{93}$ : 444-449

Sigler M, Handt S, Seghaye MC, von Bernuth G, Grabitz, RG (2000): Evaluation of in vivo biocompatibility of different devices for interventional closure of the patent ductus arteriosus in an animal model. Heart $\underline{83}$ : 570-573

Sigler M, Paul T, Grabitz RG (2005): Biocompatibility screening in cardiovascular implants. Z Kardiol 94: 383-391

Sigler M, Jux C, Ewert P (2006): Histopathological Workup of an Amplatzer Atrial Septal Defect Occluder After Surgical Removal. Pediatr Cardiol 27: 775-776 
Sigwart U, Puel J, Mirkovitch V, Joffre F, Kappenberger L (1987): Intravascular stents to prevent occlusion and restenosis after transluminal angioplasty. $\mathrm{N}$ Engl $\mathrm{J}$ Med $\underline{316}$ : 701-706

Tang DD (2008): Intermediate filaments in smooth muscle. Am J Physiol Cell Physiol 294: C869-C878

Varcoe RL, Mikhail M, Guiffre AK, Pennings G, Vicaretti M, Hawthorne WJ, Fletcher JP, Medbury HJ (2006): The role of the fibrocyte in intimal hyperplasia. J Thromb Haemost 4: 1125-1133

Vogt MO, Kühn A, Hörer J, Schreiber C, Schneider H, Foth R, Eicken A, Hess J, Sigler M (2009): Clinical, echocardiographic and histopathologic findings in nine patients with surgically explanted ASD/PFO devices: Do we know enough about the healing process in humans? Int J Cardiol - im Druck

Zalewski A, Shi Y, Johnson AG (2002): Diverse origin of intimal cells: smooth muscle cells, myofibroblasts, fibroblasts, and beyond? Circ Res 91: 652-655 


\title{
Immunohistochemical Characterization of Neotissues and Tissue Reactions to Septal Defect-Occlusion Devices
}

\author{
Rudi Foth, MD; Thomas Quentin, PhD; Ina Michel-Behnke, MD; Manfred Vogt, MD; Thomas Kriebel, MD; \\ Anne Kreischer; Wolfgang Ruschewski, MD; Thomas Paul, MD; Matthias Sigler, MD
}

Background-We sought to evaluate tissue reactions within and at the surface of devices for interventional therapy of septal defects and to identify antigen characteristics of neotissues.

Methods and Results-Atrial or ventricular septal defect-occlusion devices (Amplatzer, n=7; Cardioseal/Starflex, $\mathrm{n}=3$ ) were processed using a uniform protocol after surgical removal from humans (implantation time, 5 days to 4 years). Devices were fixed in formalin and embedded in methylmethacrylate. Serial sections were obtained by sectioning with a diamond cutter and grinding, thus saving the metal/tissue interface for histologic evaluation. Immunohistochemical staining was performed using conventional protocols. Superficial endothelial cells stained positive for von Willebrand factor. Within the newly formed tissues, fibroblast-like cells were identified with a time-dependent expression of smooth muscle cell maturation markers (smooth muscle actin, smooth muscle myosin, h-caldesmon, and desmin) beside extracellular matrix components. Neovascularization of the newly formed tissues was demonstrated with the typical immunohistochemical pattern of capillaries and small vessels. Inflammatory cells could be identified as macrophages $(\mathrm{CD} 68+)$ and both T-type and B-type lymphocytes $(\mathrm{CD} 3+$, CD79+).

Conclusions - This is the first presentation of results from serial immunohistochemical staining of a collection of explanted human septal-occlusion devices. A time-dependent maturation pattern of the fibroblast-like cells in the neotissues around the implants could be described. Neoendothelialization was seen in all specimens with implantation times of 10 weeks or more. The time course of neoendothelialization, as seen in our study, further supports the clinical practice of anticoagulant or antiplatelet therapy for 6 months after implantation. This time interval should be sufficient to prevent thromboembolic events due to thrombus formation at the foreign surface of cardiovascular implants. (Circ Cardiovasc Intervent. 2009;2:90-96.)

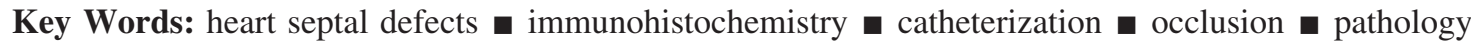

$\mathrm{C}$ linical interest and information in literature on transcatheter closure of septal defects are generally focused on feasibility, safety, and long-term clinical outcome. Because the implants remain in the human heart for lifetime, biocompatibility has additionally emerged into the focus of interest. ${ }^{1}$ Hitherto, there are few data on histopathology of explanted occlusion devices for atrial and ventricular septal defects. ${ }^{1-4}$ Concerning immunohistochemical characterization of tissue reactions, data are scarce. Just a single "clinical vignette" presenting a figure of an immunohistochemically labeled specimen has been published so far. ${ }^{5}$

\section{Clinical Perspective see p 96}

The purpose of this work was to characterize cellular and extracellular matrix (ECM) components that are formed within and around the devices after implantation and to illuminate the previously unknown way of ingrowth.

\section{Methods}

\begin{abstract}
Devices
The Amplatzer septal defect occluder (AGA Medical Corporation, Golden Valley, Minn) is a self-expanding device made from nitinol wire mesh. It has a double disc shape and consists of two retention disks with a short connecting cylindrical main body, into which polyester fibers are sewn. Devices for atrial septal defects and ventricular septal defects differ slightly in design.

The Cardioseal/Starflex device (NMT Medical Inc, Boston, Mass) is constructed of a metal (MP35N) "double-umbrella" configured framework to which polyester fabric patches are attached on both sides. The only difference between the 2 implants is the addition of a nonferromagnetic centering spring in the Starflex device.
\end{abstract}

Received July 28, 2008; accepted January 7, 2009

From the Department of Pediatric Cardiology and Pediatric Intensive Care Medicine (R.F., T.Q., T.K., T.P., M.S.), Georg-August University, Goettingen, Germany; Pediatric Heart Center (I.M.B.), Justus-Liebig University, Giessen, Germany; Department of Pediatric Cardiology and Congenital Heart Disease (M.V.), German Heart Center Munich at the Technical University, Munich, Germany; and Department of Thoracic and Cardiovascular Surgery (W.R.), Georg-August University, Goettingen, Germany.

Correspondence to Matthias Sigler, MD, Department of Pediatric Cardiology and Pediatric Intensive Care Medicine, Georg-August University Goettingen, Robert Koch Strasse 40, D 37099 Goettingen, Germany. E-mail msigler@gwdg.de

(C) 2009 American Heart Association, Inc. 
Table 1. List of Specimens for Histopathologic Workup

\begin{tabular}{llcc}
\hline & & Implantation & \\
Patient & Implant & Time & Indication for Explantation \\
\hline 1 & Amplatzer ASD & 5 days & Malpositioning \\
2 & Amplatzer VSD & 10 weeks & Valve incompetence \\
3 & Amplatzer VSD & 7 months & Malpositioning \\
4 & Amplatzer VSD & 10 months & Malpositioning \\
5 & Amplatzer ASD & 12 months & Malpositioning \\
6 & Amplatzer ASD & 15 months & Residual shunt \\
7 & Amplatzer ASD & 24 months & Residual shunt \\
8 & Cardioseal & 25 months & Residual shunt \\
9 & ASD & & \\
& Cardioseal & 36 months & Atypical configuration of the \\
& ASD & & device \\
10 & Starflex ASD & 48 months & Recurrent \\
& & & neurology/apoplexy \\
\hline
\end{tabular}

Human specimens $(n=10)$. ASD indicates atrial septal defect; VSD, ventricular septal defect.

\section{Human Explants}

Ten human tissue specimens were collected during corrective surgery at 5 centers and sent to us for routine histopathologic workup. The time intervals between implantation and explantation of septal defect-occlusion devices ranged from 5 days to 48 months. Indications for device explantations are summarized in Table 1.

\section{Tissue Preparation}

Immediately after explantation, the tissue block containing the implant was dissected free with a minimum of surrounding tissue.
After briefly flushing with saline, the specimens were fixed in formalin (buffered 4\%).

\section{Embedding, Sectioning, and Histology}

To obtain immunostaining of resin-embedded specimen, the sections were mounted on glass slides using silicon glue and underwent deplastification, as described previously. ${ }^{6}$

Staining with Richardson blue, Movat pentachrome, or Picrosirius red was performed according to standard protocols. For Richardson blue staining of resin-embedded specimen, the sections were mounted on plastic slides and stained without deplastification. For Movat pentachrome and Picrosirius red staining, the resin-embedded specimens were mounted on glass slides and deplastificated as for immunostainings.

Before embedding, macroscopic evaluation and documentation was accomplished. After fixation, the tissue block with the device was embedded in resin methylmethacrylate (Technovit 9100, Kulzer \& Co, Wehrheim, Germany). After hardening, the resin blocks were subsequently sectioned in slices of $0.8 \mathrm{~mm}$ using a diamond band saw (300 CP, Exakt GmbH, Norderstedt, Germany). These slices were grinded down to 5 to $30 \mu \mathrm{m}$ with a horizontal rotatory grinder and polisher (400 CS, Exakt GmbH).

\section{Immunohistochemistry}

Details of the staining protocols are shown in Table 2. Umbilical cord sections served as positive controls for immunostaining of smooth muscle markers and human tonsil sections for immune cells, respectively. Negative controls were processed without the antigen-specific antibody.

\section{Nomenclature}

To clarify the assignment of findings to different regions in the specimen, the following terms were used, as shown in Figure 1:

Table 2. Pretreatment and Dilutions of Antibodies for Immunohistochemical Labeling

\begin{tabular}{|c|c|c|c|}
\hline Primary Antibody & Dilution & Antigen Retrieval & Secondary Antibody \\
\hline $\begin{array}{l}\text { Mouse antihuman desmin, clone D9 } \\
\text { (Progen Biotechnik GmbH) }\end{array}$ & $1: 50$ & $\begin{array}{l}\text { Basic buffer, pH } 9 \text { (Target Retrieval Solution, } \\
\text { High pH, Dako), } 20 \text { minutes in a steamer }\end{array}$ & $\begin{array}{l}\text { Rabbit antimouse immunoglobulin antibody (Dako), } \\
\text { diluted 1:100 }\end{array}$ \\
\hline $\begin{array}{l}\text { Mouse antihuman smooth muscle } \\
\text { myosin heavy chain, clone ID8 } \\
\text { (Chemico International) }\end{array}$ & $\begin{array}{l}\text { Paraffine 1:100 } \\
\text { Resin 1:500 }\end{array}$ & $\begin{array}{c}\text { Citrate buffer, pH } 6 \text { (Dako REAL Target } \\
\text { Retrieval Solution), } 40 \text { minutes in a steamer }\end{array}$ & EnVision amplification system \\
\hline $\begin{array}{l}\text { Mouse antivimentin, clone V9 } \\
\text { (Dako) }\end{array}$ & $1: 100$ & $\begin{array}{c}\text { Citrate buffer, } \mathrm{pH} 6,40 \text { minutes in a } \\
\text { steamer }\end{array}$ & EnVision amplification system \\
\hline $\begin{array}{l}\text { Mouse antihuman smooth muscle } \\
\text { actin, clone } 1 \mathrm{~A} 4 \text { (Dako) }\end{array}$ & $1: 50$ & $\begin{array}{c}\text { Citrate buffer, } \mathrm{pH} 6,40 \text { minutes in a } \\
\text { steamer }\end{array}$ & $\begin{array}{l}\text { Rabbit antimouse immunoglobulin antibody (Dako), } \\
\text { diluted 1:100 }\end{array}$ \\
\hline $\begin{array}{l}\text { Polyclonal rabbit antihuman von } \\
\text { Willebrand factor (Dako) }\end{array}$ & $1: 400$ & $\begin{array}{l}\text { Citrate buffer, } \mathrm{pH} 6,40 \text { minutes in a } \\
\text { steamer }\end{array}$ & $\begin{array}{l}\text { Swine antirabbit immunoglobulin antibody (Dako), } \\
\text { diluted 1:100 }\end{array}$ \\
\hline $\begin{array}{l}\text { Mouse antihuman caldesmon, clone } \\
\text { h-CD (Dako) }\end{array}$ & $\begin{array}{l}\text { Paraffine 1:100 } \\
\text { Resin 1:400 }\end{array}$ & $\begin{array}{l}\text { Proteinase K (Dako, diluted } 1: 500 \text { in } \\
50 \mathrm{mmol} / \mathrm{L} \mathrm{TBS} \text {, pH } 7.6 \text { ) at } 37^{\circ} \mathrm{C} \text { for } 5 \\
\text { minutes, followed by citrate buffer, } \mathrm{pH} 6 \text { for } \\
40 \text { minutes in a steamer }\end{array}$ & EnVision amplification system \\
\hline $\begin{array}{l}\text { Polyclonal rabbit antihuman CD3 } \\
\text { (Dako) }\end{array}$ & $1: 100$ & $\begin{array}{c}\text { Citrate ph } 6 \text { (Dako), } 40 \text { minutes in a } \\
\text { steamer }\end{array}$ & $\begin{array}{c}\text { Polyclonal rabbit antigoat } \\
\text { immunoglobulin/horseradishperoxidase (Dako), } \\
\text { diluted } 1: 100\end{array}$ \\
\hline $\begin{array}{l}\text { Monoclonal mouse antihuman } \\
\text { CD79 } \alpha \text { cy, clone HM57 (Dako) }\end{array}$ & $1: 100$ & Tris/EDTA, ph 9, 20 minutes in a steamer & $\begin{array}{l}\text { Rabbit antimouse immunoglobulin (Dako), diluted } \\
\qquad 1: 100\end{array}$ \\
\hline $\begin{array}{l}\text { Monoclonal mouse antihuman } \\
\text { CD68, clone PG-M1 (Dako) }\end{array}$ & $1: 200$ & Tris/EDTA, ph 9, 20 minutes in a steamer & $\begin{array}{l}\text { Rabbit antimouse immunoglobulin (Dako), diluted } \\
\qquad 1: 100\end{array}$ \\
\hline $\begin{array}{l}\text { Monoclonal mouse anticollagen III } \\
\text { (Acris) }\end{array}$ & $1: 500$ & $\begin{array}{c}\text { Citrate buffer, ph } 6,40 \text { minutes in a } \\
\text { steamer }\end{array}$ & $\begin{array}{l}\text { Rabbit antimouse immunoglobulin antibody (Dako), } \\
\text { diluted 1:100 }\end{array}$ \\
\hline $\begin{array}{l}\text { Monoclonal mouse antifibrin (No. } \\
\text { 0.350) (American Diagnostica Inc) }\end{array}$ & $1: 500$ & $\begin{array}{l}\text { Citrate buffer, ph } 6,40 \text { minutes in a } \\
\text { steamer }\end{array}$ & $\begin{array}{l}\text { Rabbit antimouse immunoglobulin antibody (Dako), } \\
\text { diluted 1:100 }\end{array}$ \\
\hline
\end{tabular}




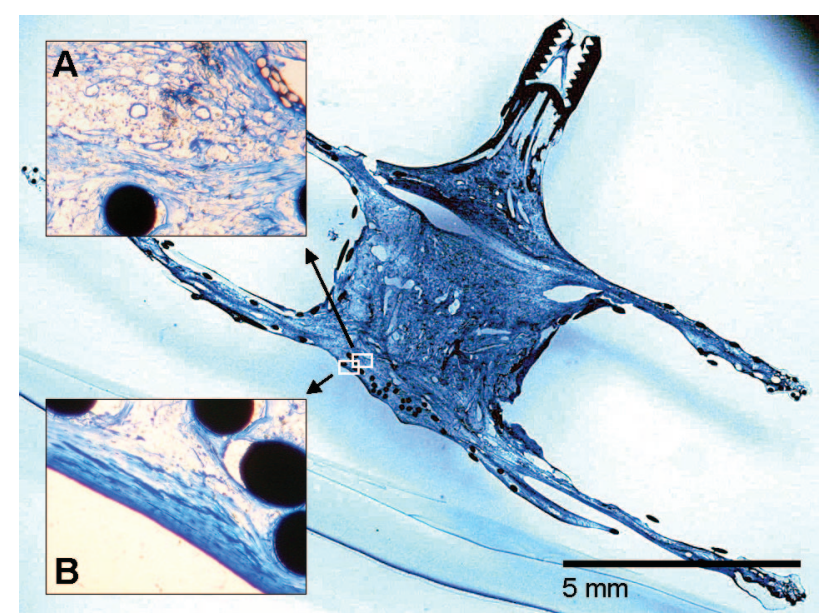

Figure 1. Micrographs show representative staining with Richardson blue (cellular components, blue; metal wires, black). Overview of an Amplatzer atrial septal defect-occlusion device 24 months after implantation (patient 7). A, Representative image of pattern of neotissue within the implant with irregular orientation of cells (detail). B, Representative image of pattern of cells of pseudointima with longitudinal orientation (parallel to the neoendothelium, detail).

1. "Neoendothelium" for the superficial cell layer if present;

2. "Pseudointima" for the tissue between the neoendothelium and the implant; and

3. "Neotissue" within the implant for tissue inside fabric and metal wires of the implant.

The term pseudointima was used according to previous descriptions of this type of tissue that is being formed intracardially after device implantation. ${ }^{1,2}$

\section{Statement of Responsibility}

The authors had full access to the data and take responsibility for its integrity. All authors have read and agree to the manuscript as written.

\section{Results}

Presentation of results is focused on immunohistochemical labeling and results of Movat pentachrome and Picrosirius red staining. Results of macroscopic evaluation and standard histology were, in part, presented and discussed previously by our group. ${ }^{1}$

\section{Neoendothelium}

Macroscopically, the Amplatzer atrial septal defect occluder with an implantation time of only 5 days (patient 1) was covered with a thin layer of dull grayish material (Figure 2A). By means of immunostaining, this superficial material could be identified as fibrin with included blood cells (Figure 2B). All other devices with implantation times of $\geq 10$ weeks were covered by a shining layer of whitish tissue of variable thickness macroscopically (Figure 2C). Endothelialization was complete, except for some prominent parts of the occluder of patient 2. Von Willebrand factor stained positive in all these specimen (Figure 2D). Results of immunostainings are summarized in Table 3.

\section{Fibrin Deposition}

Formation of condensed fibrin with included blood cells around the foreign material was the principle finding in the

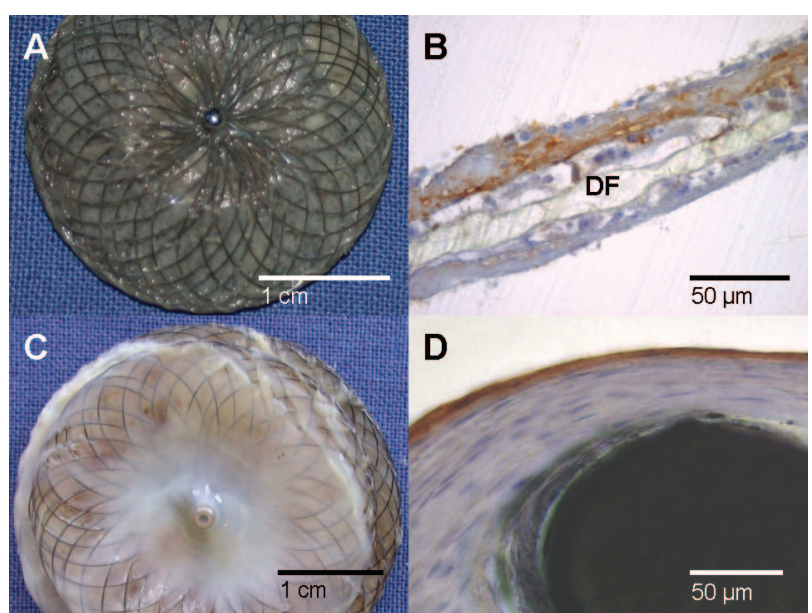

Figure 2. A, Macroscopic aspect of an Amplatzer atrial septal defect occluder with an implantation time of 5 days (patient 1). $\mathrm{B}$, Corresponding immunohistochemical staining with fibrin adjacent to Dacron fibers (DF; positive immunohistochemical staining, brown). C, Macroscopic aspect of an Amplatzer atrial septal defect occluder with an implantation time of 15 months (patient 6). D, Corresponding immunohistochemical staining with von Willebrand factor demonstrating positive labeling of neoendothelium (positive immunohistochemical staining, brown; metal wire, black).

specimen, with an implantation time of 5 days (Figure 3A). In the superficial portion of this fibrin deposit, single longitudinally oriented cells were seen. These cells stained positive for vimentin (Figure 3B), but not for other muscle cell markers.

Residual islets of fibrin deposits were observed in single specimen with implantation times of up to 15 months (Figure $3 C)$. These fibrin residues were solely seen in the central portion of the implants. In all other specimen with implantation times of $\geq 24$ months, there was no evidence of thrombotic material within the implants.

\section{Pseudointima}

Except for the implant with an implantation time of 5 days, all specimen with an implantation time $\geq 10$ weeks had a well-definable pseudointima with an organized cellular arrangement. The cells of the pseudointima showed a predominantly longitudinal orientation (parallel to the neoendothelium; Figure 1B) and stained positive for vimentin in all specimen (Figure 4A). In addition, staining was positive for the muscle cell marker smooth muscle actin and smooth muscle myosin (Figure 4B and 4C). h-caldesmon as a marker of mature smooth muscle cells was detected in a single specimen with an implantation time of 15 months (Figure 4D). Desmin stained positive in 2 specimens with implantation times of 10 months and 48 months.

By means of Movat pentachrome stain, proteoglycanes were identified as the main component of ECM within the pseudointima. In addition, collagen and few elastic fibers were seen. Immunohistochemically, antibodies against collagen III stained positive with a homogeneous distribution pattern.

Few capillaries and small vessels could be detected within the pseudointima. The cells lining the lumen of the capillaries stained positive with antibodies against von Wille- 
Table 3. Staining Patterns of Primary Antibodies

\begin{tabular}{|c|c|c|c|c|c|c|c|c|c|c|c|}
\hline \multirow[b]{2}{*}{ Neotissue } & \multirow[b]{2}{*}{ Stainings } & \multicolumn{10}{|c|}{ Septal Defect-0cclusion Devices (Implantation Time) } \\
\hline & & $\begin{array}{c}\text { Amplatzer } \\
\text { ASD } \\
\text { (5 Days) }\end{array}$ & $\begin{array}{c}\text { Amplatzer } \\
\text { VSD } \\
\text { (2 Months) }\end{array}$ & $\begin{array}{l}\text { Amplatzer } \\
\text { VSD } \\
\text { (7 Months) }\end{array}$ & $\begin{array}{c}\text { Amplatzer } \\
\text { VSD } \\
\text { (10 Months) }\end{array}$ & $\begin{array}{c}\text { Amplatzer } \\
\text { VSD } \\
\text { (12 Months) }\end{array}$ & $\begin{array}{c}\text { Amplatzer } \\
\text { ASD } \\
\text { (15 Months) }\end{array}$ & $\begin{array}{c}\text { Amplatzer } \\
\text { ASD } \\
\text { (24 Months) }\end{array}$ & $\begin{array}{c}\text { Cardioseal } \\
\text { ASD } \\
\text { (25 Months) }\end{array}$ & $\begin{array}{c}\text { Cardioseal } \\
\text { ASD } \\
\text { (36 Months) }\end{array}$ & $\begin{array}{c}\text { Starflex } \\
\text { ASD } \\
\text { (48 Months) }\end{array}$ \\
\hline Surface & vWF & - & + & + & ++ & ++ & ++ & ++ & + & ++ & + \\
\hline \multirow[t]{5}{*}{ Pseudointima } & Vimentin & ++ & ++ & nd & ++ & + & ++ & ++ & ++ & ++ & ++ \\
\hline & SMA & - & ++ & nd & nd & ++ & ++ & nd & nd & nd & + \\
\hline & SMM & - & - & - & ++ & ++ & - & - & + & - & ++ \\
\hline & h-cald & - & - & - & - & - & + & - & - & - & - \\
\hline & Desmin & - & nd & - & ++ & - & - & nd & - & - & ++ \\
\hline \multirow{5}{*}{$\begin{array}{l}\text { Tissue within } \\
\text { the implant }\end{array}$} & Vimentin & ++ & ++ & nd & ++ & + & ++ & ++ & ++ & ++ & ++ \\
\hline & SMA & - & ++ & nd & nd & ++ & ++ & nd & nd & nd & ++ \\
\hline & SMM & - & + & - & ++ & ++ & - & - & - & - & ++ \\
\hline & h-cald & - & - & - & - & - & + & - & - & - & - \\
\hline & Desmin & - & nd & - & + & - & - & nd & - & - & - \\
\hline
\end{tabular}

ASD indicates atrial septal defect; VSD, ventricular septal defect; vWF, von Willebrand factor; SMA, smooth muscle actin; SMM, smooth muscle myosin; h-cald h-caldesmon; -, negative; + , positive; ++ , strong positive.

brand factor and vimentin (Figure 5A). In addition, cells in the wall of the small vessels showed positive staining for smooth muscle actin, smooth muscle myosin, and $\mathrm{h}$-caldesmon even in specimen with implantation times of only 10 weeks (Figure 5B).

\section{Neotissue Within the Implant}

The neotissue within the implant can be clearly distinguished from the formerly described pseudointima (1) by its localization, (2) by the configuration of cellular and extracellular components, and (3) by its rich vascularization opposed to the sporadic appearance of capillaries within the pseudointima. It morphologically consisted of areolar connective tissue with mostly irregular oriented cells (Figure 1A). These cells stained positive with antibodies against vimentin, smooth muscle actin, and smooth muscle myosin (Figure 6A and 6B). Additional positive staining for desmin and h-caldesmon was found in a single specimen with implantation times of more than 10 months.

As described earlier for the pseudointima, capillaries within the implant stained positive for von Willebrand factor, vimentin, smooth muscle actin, smooth muscle myosin, and h-caldesmon (Figure 5A and 5B).

ECM components were analyzed by means of Movat pentachrome stain and immunohistochemical labeling with

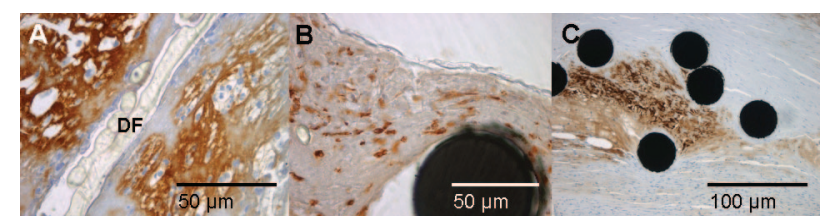

Figure 3. Micrographs show representative immunohistochemical staining of fibrin deposits (positive immunohistochemical staining, brown; metal wires, black). A, Fibrin staining of a specimen with an implantation time of 5 days (patient 1 ). B, Micrograph of vimentin staining in the same patient. C, Micrograph of fibrin staining in patient 6 (implantation time 15 months). DF indicates Dacron fibers. antibodies against collagen III (Figure 6C). Proteoglycanes were identified as the main constituent of this part of the specimen besides collagen and few elastic fibers (Figure 6D). Composition of ECM components was not different in the parts adjacent to Dacron fibers and metal parts of the implants.

\section{Inflammation}

Foreign body giant cells were seen usually in local relation to Dacron fibers. These cells stained positive with antibodies against vimentin and CD68 (Figure 7A). In almost all

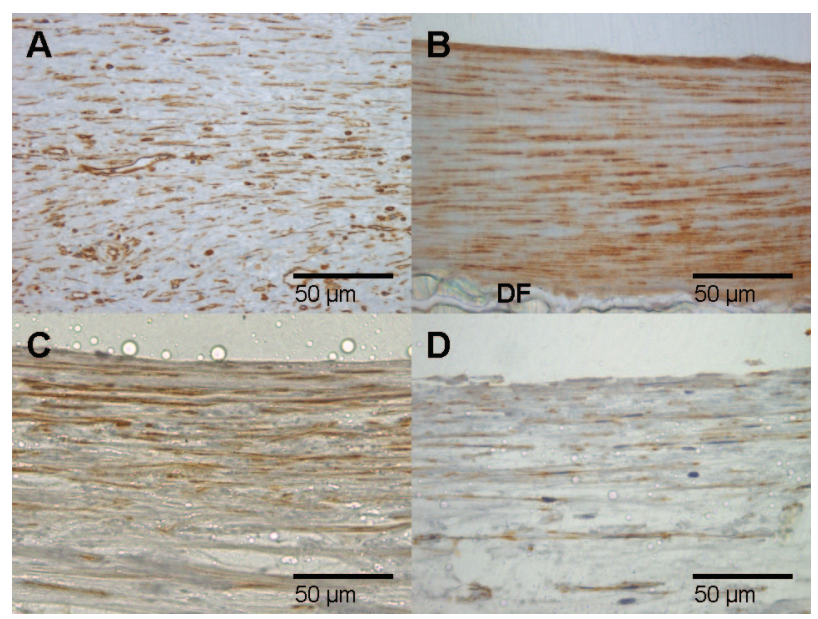

Figure 4. Micrographs show representative immunohistochemical staining of cellular components of the pseudointima with typical longitudinal orientation of cells and few capillarization (positive immunohistochemical staining, brown). A, Micrograph of vimentin staining of a specimen with an implantation time of 48 months (patient 10). B, Micrograph of smooth muscle actin staining of a specimen with an implantation time of 12 months (patient 5). C, Micrograph of smooth muscle myosin staining of a specimen with an implantation time of 12 months (patient 5). $\mathrm{D}$, Micrograph of $\mathrm{h}$-caldesmon staining of a specimen with an implantation time of 15 months (patient 6). DF indicates Dacron fibers. 


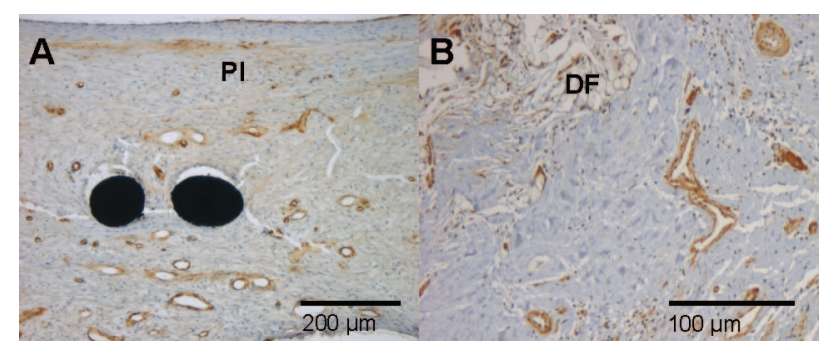

Figure 5. Micrographs show representative immunohistochemical staining of capillaries and small vessels (positive immunohistochemical staining, brown; metal wires, black). A, Micrograph of von Willebrand factor staining of a specimen with an implantation time of 10 weeks (patient 2). B, Micrograph of smooth muscle actin staining of a specimen with an implantation time of 48 months (patient 10). PI indicates pseudointima; DF, Dacron fibers.

explants, inflammatory infiltrates with lymphocytes were observed within the implant. In 2 of the implants, marker for $\mathrm{T}$ cell and $\mathrm{B}$ cell was used for further differentiation. In both specimen, lymphocytes stained positive with antibodies against the T-cell marker CD3 and with the B-cell marker CD79 (Figure 7B and 7C).

The clinically most important aspects of the healing response (neoendothelialization and cellular organization of initially formed fibrin deposits) after implantation of a septal defect-occlusion device are summarized in Table 4.

\section{Discussion}

To the best of our knowledge, this is the first study that characterizes tissue reactions in a series of human explanted septal defect-occlusion devices by means of immunohistochemistry. Two of the currently and most commonly used

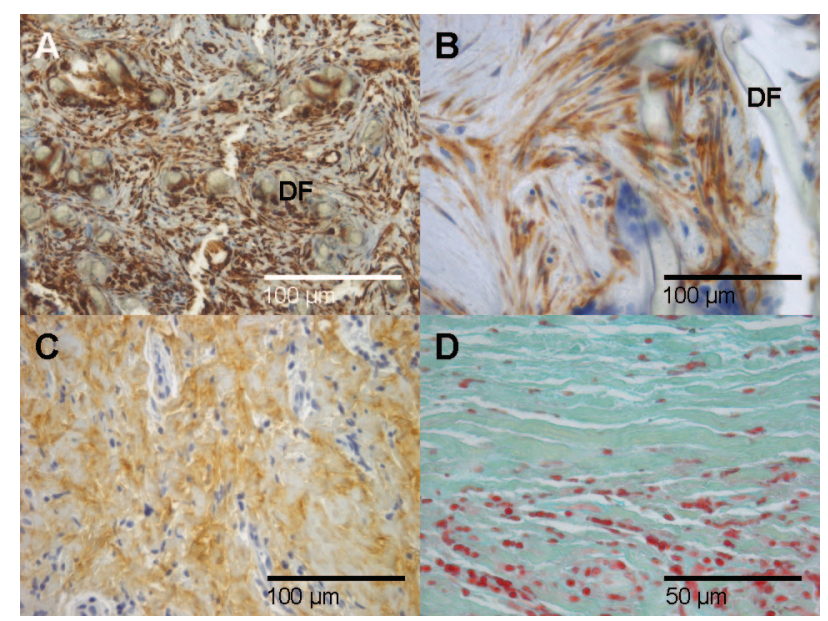

Figure 6. Micrographs show representative immunohistochemical staining or Movat pentachrome staining of cellular and ECM components of tissue within the implant with typical irregular orientation of cells (positive immunohistochemical staining, brown). A, Micrograph of vimentin staining of a specimen with an implantation time of 10 months (patient 4). B, Micrograph of smooth muscle actin staining of a specimen with an implantation time of 15 months (patient 6). C, Micrograph of collagen III staining of a specimen with an implantation time of 48 months (patient 10). D, Micrograph of Movat pentachrome staining (proteoglycanes, bluish green; cell nuclei, red; collagen, yellow) of a specimen with an implantation time of 48 months (patient 10). DF indicates Dacron fibers.

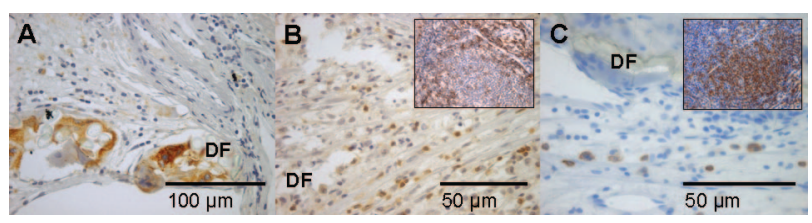

Figure 7. Micrographs show representative immunohistochemical staining of inflammatory cells (positive immunohistochemical staining, brown). A, Micrograph of CD68 staining labeling foreign body giant cells adjacent to Dacron fibers (DF) in a specimen with an implantation time of 36 months (patient 9). B, Micrograph of CD3 staining with positive labeling of T lymphocytes in a specimen with an implantation time of 48 months (patient 10). C, Micrograph of CD79 staining with positive labeling of $B$ lymphocytes in a specimen with an implantation time of 15 months (patient 6). Details of panels B and C show positive controls in methylmethacrylate-embedded human tonsil.

septal occluders, the Amplatzer and Cardioseal/Starflex devices, were evaluated in our study.

Except for 1 case report, no immunohistochemical stainings of explanted septal defect-occlusion devices have been published so far. ${ }^{5}$ This may be for the most part because of the technical challenge to perform immunohistochemistry in hard resin-embedded specimen. ${ }^{7,8}$ The need for deplastification of the grinded sections to uncover antigens aggravates the complexity of specimen processing. ${ }^{8}$ In addition, establishment of primary antibodies in resin-embedded specimen requires far more time and effort as compared to paraffin wax-embedded specimen.

Neoendothelialization of septal defect-occlusion devices after interventional application is of major clinical relevance because superficial thrombus formation is a possible source for embolism and subsequent organ damage. ${ }^{9}$ For prevention, most centers give antiplatelet or anticoagulant therapy for 6 months until neoendothelialization is expected to be completed.

In animal studies and human explants, endothelial cells were observed as soon as 30 days after implantation. ${ }^{1}$ In previous publications, these characterizations were accomplished solely by standard stain or scanning electron microscopy. ${ }^{3,4}$ In this study, we were able to identify endothelial cells by means of immunohistochemical labeling for the first time. Antibodies against von Willebrand factor and vimentin stained positive superficial cells in all specimen with implantation times $\geq 10$ weeks. Thus, we could demonstrate functional properties in addition to formerly described morphologic characteristics of endothelium on the intracardial surface of the implants.

After implantation of septal defect-occlusion devices, initial formation of thrombotic material in-between metal wires and around polyester fibers has been described. This

Table 4. Healing Response Over Time

\begin{tabular}{lccc}
\hline & \multicolumn{3}{c}{ Implantation Time } \\
\cline { 2 - 4 } Localization & 5 Days & 2-15 Months & $\geq 24$ Months \\
\hline Surface & Fibrin & Endothelial cells & Endothelial cells \\
Pseudointima & Fibrin/cells & Cells & Cells \\
Tissue within the implant & Fibrin & Fibrin/cells & Cells \\
\hline
\end{tabular}


thrombotic material has been demonstrated to be transformed to connective tissue consisting of mainly ECM and embedded cellular components, which morphologically resemble fibroblast-like cells in septal defect-occlusion devices ${ }^{1}$ and occlusion devices for other applications. ${ }^{10}$ The results of our present study give some insight into the time course of this process, as cellular organization of fibrin deposits was advanced after 10 weeks already, but completed after 24 months only (Table 4).

To further characterize the "fibroblast-like" cells within the newly formed tissue, we used a panel of muscular maturation marker. The cells seen in the pseudointima and within the implant concordantly stained positive for the mesenchymal marker, vimentin, and the early muscular differentiation marker, smooth muscle actin and smooth muscle myosin, resembling a myofibroblast-like phenotype. ${ }^{11} \mathrm{~h}$-caldesmon is part of the contractile apparatus of muscle cells and is regarded as a marker for mature and highly differentiated muscle cells. ${ }^{12,13}$ In our series, it only stained positive in a single specimen with implantation times of 15 months. Likewise, desmin as a marker for intermediate filaments is expressed in highly differentiated muscle cells. ${ }^{12,14}$ The late occurrence of desmin and h-caldesmon in our specimen can be taken as signs for the slow progression of cell maturation after device implantation. Concerning immunostaining, there were no differences between cells in the pseudointima (longitudinally orientated) and cells within the implant (irregularly orientated).

Cells in close local relation to metal struts stained positive for vimentin, smooth muscle actin, and smooth muscle myosin independently of the implantation time. Thus, we found no evidence for a possible toxic reaction to metal ions, because release of nickel ions from metal wires of septal defectocclusion devices is a well-described phenomenon. ${ }^{15,16}$

In analyzing the newly formed tissues around occlusion devices, the specimen with the shortest implantation time of only 5 days is of special interest. Besides the typical pattern of thrombus with fibrin septations and included blood cells, occurrence of some vimentin positive fibroblast-like cells could be demonstrated. These fibroblast-like cells could be fibrocytes. Fibrocytes are circulating cells, which migrate into wounds and adopt a smooth muscle-like phenotype (spindle-shape morphology, positive staining for vimentin, and smooth muscle actin). Varcoe et al ${ }^{17}$ demonstrated that these cells are involved in intima formation. It can be assumed that these cells are involved in the organization of the thrombotic material and the formation of the pseudointima, as seen in our collection of specimen.

With regard to ECM components, we found a similar areolar-like pattern in central parts of the specimen, as described by Kreutzer et $\mathrm{al}^{2}$ with mainly proteoglycans, besides collagen and few elastic fibers.

Multinucleated foreign body cells have constantly been observed in local relation to Dacron fibers of cardiovascular implants, such as the Amplatzer or the Cardioseal/Starflex device. ${ }^{2,4}$ Foreign body giant cells in the specimen of our study stained positive with antibodies against CD68 identifying these cells as macrophages, which are considered as being part of the innate immune response.
In addition to the foreign body reaction, mild lymphocytic infiltrations have been described within the newly formed tissue after implantation of septal defect-occlusion devices. ${ }^{1,2}$ In the present study, we were able to further differentiate this lymphocytic reaction for the first time, because we could demonstrate a lymphocytic reaction of a mixed type (CD3 and CD 79 positive). Thus, we have evidence of some kind of adaptive cellular response in addition to the reaction of the innate immune system locally related to the implants.

No difference in pattern or time course of immunohistochemistry-based findings was observed comparing Amplatzer and Cardioseal/Starflex occlusion devices, different sites of implantation (atrial septal defect versus ventricular septal defect), or indication for explantation. This is in accordance with the results of comparative analysis of standard staining of the 2 devices, as it has been reported earlier by our group. ${ }^{1}$

In summary, this study demonstrates the value of immunohistochemical staining for characterization of tissues within and around septal defect-occlusion devices after interventional implantation. We can for the first time describe antigen patterns of cells in the neotissues. Fibroblast-like cells were identified with a slowly progressing maturation pattern over time as demonstrated by immunohistochemically labeling with a variety of smooth muscle cell markers. Superficial cells could be identified as endothelial cells. The time course of neoendothelialization, as seen in our study, further supports the clinical practice of anticoagulant or antiplatelet therapy for 6 months after implantation. This time interval should be sufficient to prevent thromboembolic events due to thrombus formation at the foreign material surface of cardiovasular implants.

\section{Acknowledgments}

We thank Andrea Poppe and Karin Baer for technical assistance.

\section{Disclosures}

None.

\section{References}

1. Sigler M, Jux C. Biocompatibility of septal defect closure devices. Heart. 2007;93:444-449.

2. Kreutzer J, Ryan CA, Gauvreau K, Van Praagh R, Anderson JM, Jenkins KJ. Healing response to the Clamshell device for closure of intracardiac defects in humans. Catheter Cardiovasc Interv. 2001;54:101-111.

3. Sigler M, Jux C, Ewert P. Histopathological workup of an Amplatzer atrial septal defect occluder after surgical removal. Pediatr Cardiol. 2006;27:775-776.

4. Ahn E, Luk A, Mezody M, Horlick E, Ross H, Butany J. Early morphological changes of an Amplatzer Septal Occluder explanted at heart transplant. Cardiovasc Pathol. 2007;18:57-60.

5. Bauriedel G, Skowasch D, Peuster M. Pathology of explanted ASD occluder. Eur Heart J. 2006;28:684.

6. Quentin T, Poppe A, Bar K, Sigler A, Foth R, Michel-Behnke I, Paul T, Sigler M. A novel method for processing resin-embedded specimens with metal implants for immunohistochemical labelling. Acta Histochem. 2008; [Epub ahead of print].

7. Sigler M, Paul T, Grabitz RG. Biocompatibility screening in cardiovascular implants. Z Kardiol. 2005;94:383-391.

8. Malik N, Gunn J, Holt CM, Shepherd L, Francis SE, Newman CM, Crossman DC, Cumberland DC. Intravascular stents: a new technique for tissue processing for histology, immunohistochemistry, and transmission electron microscopy. Heart. 1998;80:509-516. 
9. Anzai H, Child J, Natterson B, Krivokapich J, Fishbein MC, Chan VK, Tobis JM. Incidence of thrombus formation on the CardioSEAL and the Amplatzer interatrial closure devices. Am J Cardiol. 2004;93:426-431.

10. Sigler M, Handt S, Seghaye MC, von Bernuth G, Grabitz RG. Evaluation of in vivo biocompatibility of different devices for interventional closure of the patent ductus arteriosus in an animal model. Heart. 2000;83: $570-573$.

11. Desmouliere A, Chaponnier C, Gabbiani G. Tissue repair, contraction, and the myofibroblast. Wound Repair Regen. 2005;13:7-12.

12. Zalewski A, Shi Y, Johnson AG. Diverse origin of intimal cells: smooth muscle cells, myofibroblasts, fibroblasts, and beyond? Circ Res. 2002; 91:652-655.

13. Frid MG, Shekhonin BV, Koteliansky VE, Glukhova MA. Phenotypic changes of human smooth muscle cells during development: late expression of heavy caldesmon and calponin. Dev Biol. 1992;153: 185-193.

14. Tang DD. Intermediate filaments in smooth muscle. Am J Physiol Cell Physiol. 2008;294:C869-C878.

15. Ries MW, Kampmann C, Rupprecht HJ, Hintereder G, Hafner G, Meyer J. Nickel release after implantation of the Amplatzer occluder. Am Heart J. 2003;145:737-741.

16. Burian M, Neumann T, Weber M, Brandt R, Geisslinger G, Mitrovic V, Hamm C. Nickel release, a possible indicator for the duration of antiplatelet treatment, from a nickel cardiac device in vivo: a study in patients with atrial septal defects implanted with an Amplatzer occluder. Int J Clin Pharmacol Ther. 2006;44:107-112.

17. Varcoe RL, Mikhail M, Guiffre AK, Pennings G, Vicaretti M, Hawthorne WJ, Fletcher JP, Medbury HJ. The role of the fibrocyte in intimal hyperplasia. J Thromb Haemost. 2006;4:1125-1133.

\section{CLINICAL PERSPECTIVE}

More than 100000 septal defect-occlusion devices have been implanted as yet. Much experience has been gained with the implantation procedure during the past years, making it a safe and effective procedure nowadays. In contrast, little is known on the healing response after implantation. To our knowledge, this study is the first systematical evaluation of tissue reactions using immunostainings in a series of 10 septal defect-occlusion devices, which were explanted from humans for malpositioning, residual shunting, or other reasons. Superficial cells could be identified as endothelial cells. The time course of neoendothelialization, as seen in our study, further supports the clinical practice of anticoagulant or antiplatelet therapy for 6 months after implantation. This time interval should be sufficient to prevent thromboembolic events due to thrombus formation at the foreign material surface of cardiovascular implants. As seen by immunohistochemical staining, the process of complete cellular organization of the initially formed fibrin deposits takes longer than previously reported. Even in a device which had been implanted for 15 months, residual islets of condensed fibrin were seen. The cellular components of the neotissue were demonstrated to mainly consist of fibroblast-like cells, which showed a slowly progressing maturation pattern over time. 
Available online at www.sciencedirect.com

\title{
A novel method for processing resin-embedded specimens with metal implants for immunohistochemical labelling
}

\author{
Thomas Quentin ${ }^{\mathrm{a}}$, Andrea Poppe ${ }^{\mathrm{a}}$, Karin Bär ${ }^{\mathrm{a}}$, Albrecht Sigler ${ }^{\mathrm{b}}$, \\ Rudi Foth $^{a}$, Ina Michel-Behnke ${ }^{c}$, Thomas Paul ${ }^{a}$, Matthias Sigler ${ }^{a, *}$
}

\author{
${ }^{a}$ Department of Pediatric Cardiology and Pediatric Intensive Care Medicine, Georg-August University, \\ D-37075 Goettingen, Germany \\ ${ }^{\mathrm{b}}$ Kinsmen Laboratory of Neurological Research, University of British Columbia, Vancouver, Canada V6T $1 Z 3$ \\ ${ }^{c}$ Pediatric Heart Center, Justus-Liebig University, D-35392 Giessen, Germany
}

Received 8 March 2008; received in revised form 26 March 2008; accepted 3 April 2008

\author{
KEYWORDS \\ Methylmethacrylate \\ embedding; \\ Immunohisto- \\ chemistry; \\ Smooth muscle; \\ Stented vessel
}

\begin{abstract}
Summary
A major technical problem in the processing of resin-embedded tissues is the adhesion of the tissue sample on glass slides for immunohistochemical labelling. We therefore established a novel protocol for processing such specimens with improved attachment of the tissue sample during resin removal (deplastification). In order to demonstrate the feasibility of the procedure we employed a panel of smooth muscle cell maturation markers. The technique makes use of a silicone glue (Elastosil E41; Wacker Chemie, München, Germany) to attach the tissue samples to the glass slides. This allows resin dissolution in xylene/2-methoxyethylacetate without detachment of the sample from the slide. Our results demonstrate successful immunohistochemical labelling with primary antibodies directed against: smooth muscle actin, smooth muscle myosin, h-caldesmon, desmin, vimentin and von Willebrand factor. In conclusion, we have established a new and successful method for resin-embedded sample adhesion on glass slides. The developed protocol is feasible for investigation of cells which are involved in intimal proliferation following stent implantation. (c) 2008 Elsevier $\mathrm{GmbH}$. All rights reserved.
\end{abstract}

\section{Introduction}

A detailed investigation of the tissue reaction around metal implants such as stents or occluders is of considerable clinical interest. For this kind of investigation, immunohistochemistry is an important

\footnotetext{
*Corresponding author. Tel.: +49551396203; fax: +49551392997.

E-mail address: msigler@gwdg.de (M. Sigler).
} 
tool to identify the different cell populations surrounding the implant. Immunohistochemistry on paraffin wax-embedded tissues is a widely used and established method; however, only relatively few studies have focused on immunohistochemical labelling on resin-embedded tissues containing metal implants. Our previous experience has shown that a major technical problem is the detachment of the resin-embedded and ground sections from the object slides during the deplastification procedure. Consequently, we tested a panel of different glues. We found that silicone glue Elastosil E41 (Wacker Chemie, München, Germany) works well for our purpose. It successfully adhered the resin block onto glass slides during the sawing and grinding procedures and allowed deplastification of the sections by incubation with xylene and 2-methoxyethylacetate (MEA), without detachment of the section. Therefore, by using this protocol we were able to establish a panel of immunohistochemical protocols for the detection of smooth muscle cell maturation markers. This allows a more detailed description of the proliferating cell types around metal implants found in the area of Tunica intima.

\section{Material and methods}

\section{Tissue samples}

Human umbilical cords were obtained from the local delivery room at our hospital. One human vascular specimen with an implanted stent was examined in order to demonstrate the applicability of our protocol to metal-containing tissue samples. The stent had been implanted in a 5-year-old child with Alagille syndrome due to significant narrowing of the main pulmonary artery. After 27 months , the stented vessel segment was removed during pulmonary valvular transplant surgery.

Human tissue samples were obtained with informed consent of the patients and studied with permission of the local ethics committee.

\section{Preparation of the sections}

Human umbilical cords and the stented pulmonary artery were immediately fixed in $4 \%$ formaldehyde solution for at least $48 \mathrm{~h}$. Subsequently, the specimens were embedded in methylmethacrylate (T9100Neu, Heraeus Kulzer, Hanau, Germany) following the protocol supplied by the manufacturer. To obtain histological slides from the hardened resin blocks, a sawing and grinding system (Exakt, Norderstedt, Germany) was employed. We used the silicone glue Elastosil E41 (Wacker Chemie $\mathrm{GmbH}$, München, Germany) for adhesion of the resin-embedded specimen onto glass slides. The resin block and the attached glass slide were kept compressed for $24 \mathrm{~h}$ at room temperature until sufficient hardening of the silicone glue was achieved. Subsequently, a 200- $\mu \mathrm{m}$-thick section was sawed parallel to the glass slide using a diamond cutter. The glass slide with the attached

Table 1. Table of antibodies used in this study

\begin{tabular}{|c|c|c|c|}
\hline Primary antibody & Dilution & Antigen retrieval & Secondary antibody \\
\hline $\begin{array}{l}\text { Mouse anti-human desmin, } \\
\text { clone D9 (Progen Biotechnik } \\
\text { GmbH, Heidelberg, } \\
\text { Germany) }\end{array}$ & $1: 50$ & $\begin{array}{l}\text { Basic buffer, pH } 9 \text { (target retrieval } \\
\text { solution, high pH, Dako), } 20 \text { min in a } \\
\text { steamer }\end{array}$ & $\begin{array}{l}\text { EnVision amplification } \\
\text { system }\end{array}$ \\
\hline $\begin{array}{l}\text { Mouse anti-human smooth } \\
\text { muscle myosin heavy chain, } \\
\text { clone ID8 (Chemico } \\
\text { International, Temicon, Ca, } \\
\text { USA) }\end{array}$ & $1: 100$ & $\begin{array}{l}\text { Citrate buffer, pH } 6 \text { (Dako REAL }{ }^{T M} \text { target } \\
\text { retrieval solution), } 40 \text { min in a steamer }\end{array}$ & $\begin{array}{l}\text { EnVision amplification } \\
\text { system }\end{array}$ \\
\hline $\begin{array}{l}\text { Mouse anti-vimentin, clone } \\
\text { V9 (Dako) }\end{array}$ & $1: 100$ & Citrate buffer, $\mathrm{pH} 6,40 \mathrm{~min}$ in a steamer & $\begin{array}{l}\text { EnVision amplification } \\
\text { system }\end{array}$ \\
\hline $\begin{array}{l}\text { Mouse anti-human smooth } \\
\text { muscle actin, clone } 1 \mathrm{~A} 4 \\
\text { (Dako) }\end{array}$ & $1: 300$ & Citrate buffer, $\mathrm{pH} 6,40 \mathrm{~min}$ in a steamer & $\begin{array}{l}\text { Rabbit anti-mouse } \\
\text { immunoglobulin antibody } \\
\text { (Dako), diluted 1:100 }\end{array}$ \\
\hline $\begin{array}{l}\text { Polyclonal rabbit anti- } \\
\text { human von Willebrand } \\
\text { factor (Dako) }\end{array}$ & $1: 400$ & Citrate buffer, $\mathrm{pH} 6,40 \mathrm{~min}$ in a steamer & $\begin{array}{l}\text { Swine anti-rabbit } \\
\text { immunoglobulin antibody } \\
\text { (Dako), diluted 1:100 }\end{array}$ \\
\hline $\begin{array}{l}\text { Mouse anti-human } \\
\text { caldesmon, clone h-CD } \\
\text { (Dako) }\end{array}$ & $1: 100$ & $\begin{array}{l}\text { Proteinase } \mathrm{K} \text { (Dako, diluted } 1: 500 \text { in } 50 \mathrm{mM} \\
\mathrm{TBS}, \mathrm{pH} 7.6 \text { ) at } 37^{\circ} \mathrm{C} \text { for } 5 \mathrm{~min} \text {, followed by } \\
\text { citrate buffer, } \mathrm{pH} 6 \text { for } 40 \mathrm{~min} \text { in a steamer }\end{array}$ & $\begin{array}{l}\text { EnVision amplification } \\
\text { system }\end{array}$ \\
\hline
\end{tabular}


$200-\mu \mathrm{m}$-thick section was ground down to approximately $10-20 \mu \mathrm{m}$ using abrasive papers with decreasing grain sizes.

Human umbilical cord specimens that had been routinely fixed and processed for paraffin wax embedding were also investigated. Five-micrometer-thick sections were cut by microtome and mounted on glass slides.

\section{Immunohistochemistry}

Deplastification of the resin-embedded specimen was carried out using the following steps: $3 \times 20$ min xylene, $1 \times 20$ min 2-MEA (Merck KgaA, Darmstadt, Germany), $2 \times 5 \mathrm{~min}$ acetone, rehydration in water for $5 \mathrm{~min}$. Paraffin wax-embedded specimens were dewaxed using xylene and rehydrated through descending alcohol concentrations.

For both types of specimens, this was followed by the process of antigen retrieval, as described in
Table 1. After washing with Tris-buffered saline (TBS, $10 \mathrm{mM}, \mathrm{pH}$ 7.6) containing $0.025 \%$ Tween (TTBS), the sections were incubated with an antibody diluent (Dako REAL ${ }^{\mathrm{TM}}$ antibody diluent, Dako, Glostrup, Denmark) for 30 min. Incubation with the primary antibody (details in Table 1) was carried out overnight in a humidified chamber at $4{ }^{\circ} \mathrm{C}$. Thereafter, the sections were washed again with TTBS and the peroxidase-conjugated secondary antibody (details in Table 1) was applied for $1 \mathrm{~h}$. If the signal was too weak, an amplification system (Envision+Dual Link System, Peroxidase, Dako) was used, employed according to the manufacturer's instructions for $30 \mathrm{~min}$, instead of the secondary antibody. Afterwards, the sections were washed again and incubated with a chromogen (liquid $D A B+$ substrate chromogen system, Dako), according to the manufacturer's instructions, for visualization of the signal. Finally, the sections were counterstained with hematoxylin (Merck), dehydrated and mounted with Entellan (Merck). All
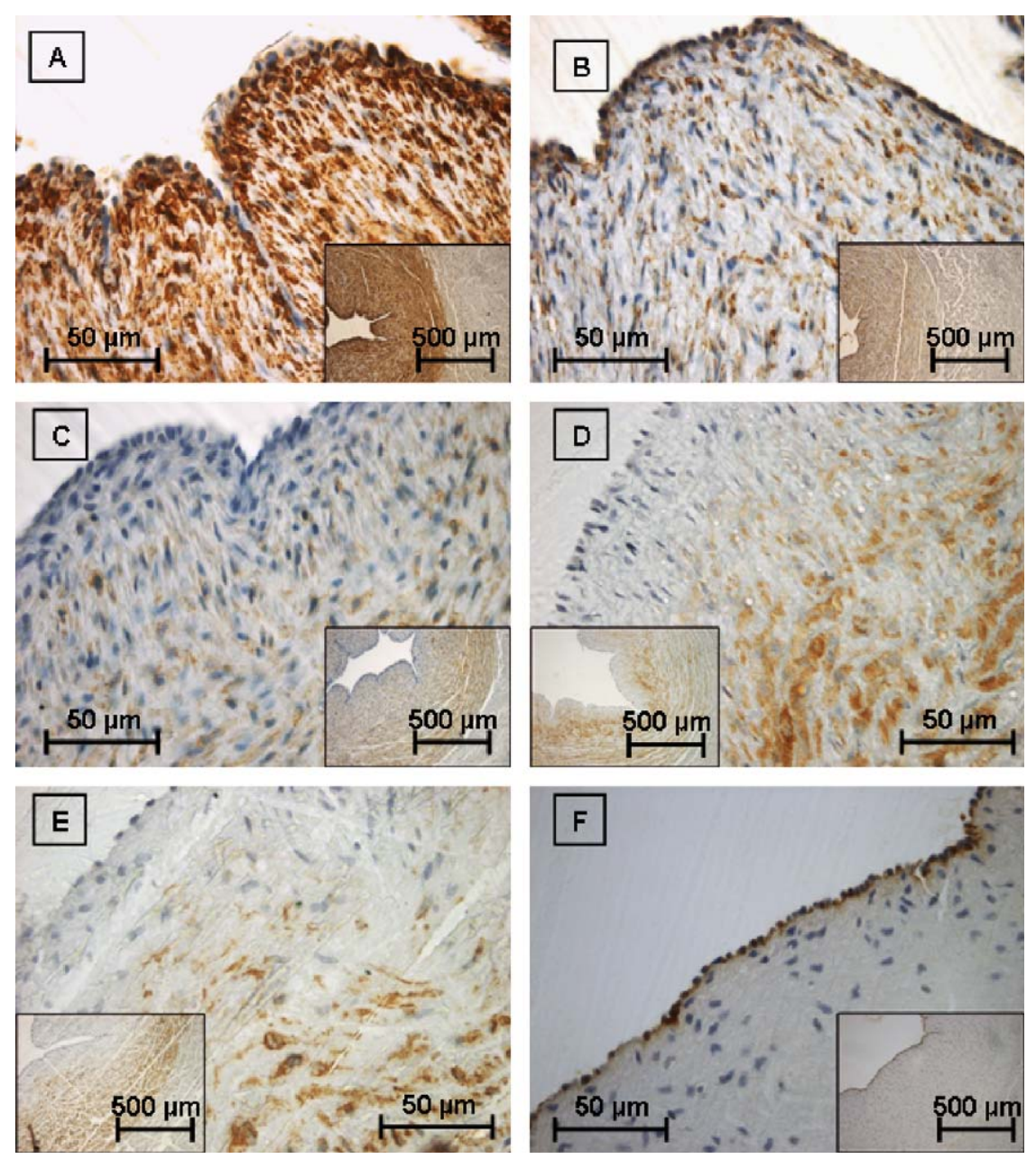

Figure 1. Sections from a human umbilical cord artery embedded in T9100 and prepared by sawing and grinding (an overview of the section is shown in the smaller picture). Immunolabelling for: (A) smooth muscle actin, (B) vimentin, (c) smooth muscle myosin, (D) h-caldesmon, (E) desmin and $(F)$ von Willebrand factor. 
steps were performed at room temperature unless otherwise specified. Negative controls were processed following the same protocol but without application of the primary antibodies.

\section{Results}

In order to ensure that the silicone glue Elastosil E41 can be used in immunohistochemical applications, we had to confirm that it did not destroy or irreversibly cover the epitopes of the antigens in the tissue slices. Therefore, we compared the immunolabelling patterns of our resin-embedded sections with paraffin-wax-embedded sections from the same tissue. As the test tissue we used umbilical cord arteries. We found no differences in the immunolabelling patterns between paraffin wax-embedded tissue sections and resin-embedded sections, prepared by sawing and grinding (data not shown). Negative controls where the primary antibodies had been omitted showed no labelling in either case.

Representative immunolabelling from resinembedded slices of umbilical arteries, prepared by sawing and grinding, are shown in Figure 1. Every immunohistochemical marker gave clear, cytoplasmic labelling. The main contractile proteins of smooth muscle cells are smooth muscle actin (SMA) and smooth muscle myosin (SM-MHC). SM-MHC was labelled in all cells of the umbilical artery wall very intensely, apart from the endothelial cells. In contrast to SMA, the labelling of SM-MHC was rather weak and the subendothelial cells were unlabelled.

The h-caldesmon (heavy-caldesmon) isoform is involved in the regulation of smooth muscle cell contraction and is a late differentiation marker for smooth muscle cells (Frid et al., 1992). The antibody gave medium to strong immunolabelling intensity, but failed to label the inner part of the umbilical arteries.

Vimentin and desmin belong to the family of intermediate filament proteins, which are required for cytoskeletal functions. We found a labelling pattern of the umbilical artery identical to the description by Johansson et al. (1999). Vimentin labelled all cells of the arterial wall, including the endothelial cells. In contrast to vimentin, desmin did not label the inner part of the media.

The antibody against the von Willebrand factor labelled endothelium.

Labelling of the von Willebrand factor in the intimal thickening of a stented pulmonary artery is shown in Figure 2. Nearly all cells of the intima labelled positive for SMA and vimentin, whereas myosin and caldesmon failed to label in these intimal cells.

\section{Discussion}

We successfully established a novel method for the preparation of resin-embedded and metal-containing
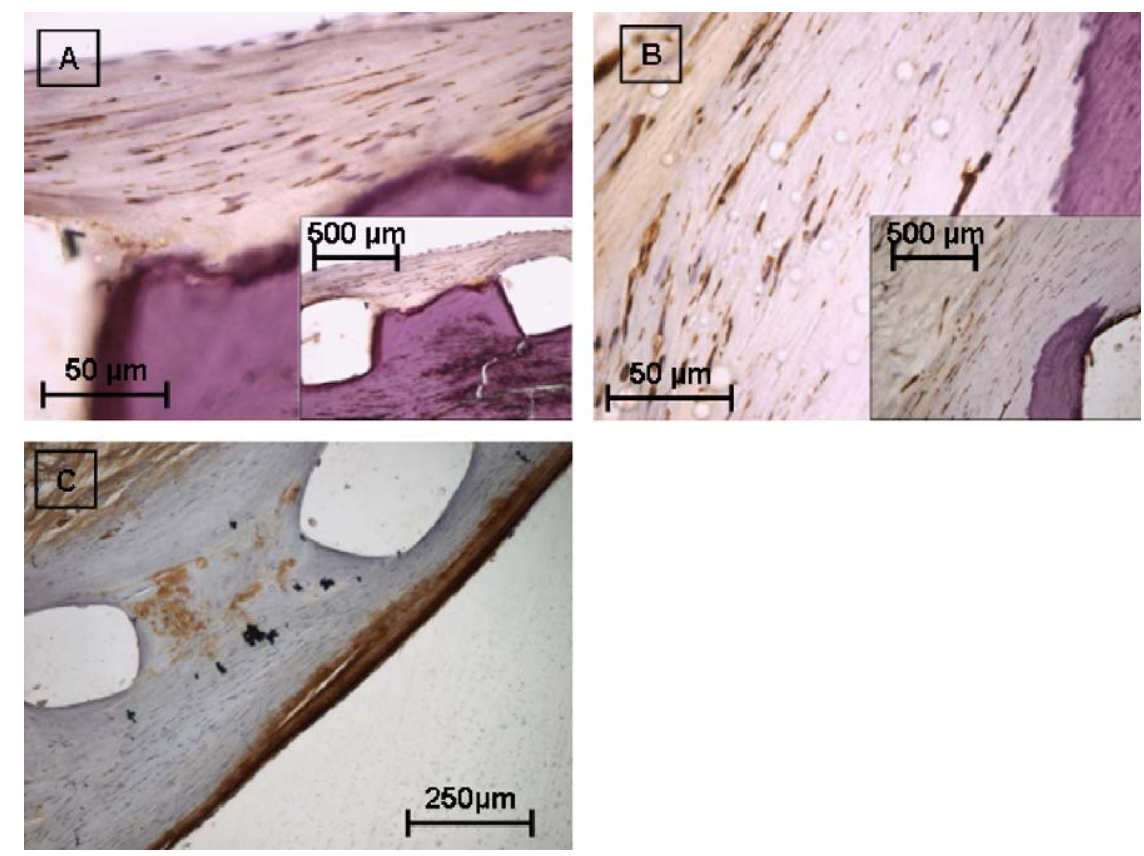

Figure 2. Sections from a stented human pulmonary artery (an overview of the section is shown in the smaller picture) embedded in T9100 and prepared by sawing and grinding. The smaller picture gives a more general view of the investigated area. Immunolabelling for: (A) smooth muscle actin, (B) vimentin and (C) von Willebrand factor. 
slices for immunohistochemistry. Morphology and immunolabelling of the resin-embedded slices were comparable to paraffin-wax-embedded sections from the same tissue, which confirms that our protocol does not alter the antigenic properties of the tissue slices. It also demonstrates that xylene/2-MEA-based deplastification dissolves all the resin out of the tissue slices, as it is the case with paraffin-waxembedded tissue slices.

The immunolabelling of the umbilical cord artery revealed that the inner part of the media consists of cells which lack a fully mature phenotype, because higher smooth muscle cell maturation markers such as SM-MHC and h-caldesmon are missing (Yoshida and Owens, 2005). In this case, they resemble the cells which can be found in the intima of the stented pulmonary artery.

The above-described protocol represents an additional tool to previously described protocols for immunohistochemistry on resin-embedded tissues published by other groups (Bräsen et al., 2001; Rammelt et al., 2007). These groups used Technovit VLC glues for the adhesion procedure and 2-MEA for deplastification of the slices. In our experience, Technovit VLC glues were less favorable because they often resulted in loss of the tissue slice during the deplastification procedure with 2-MEA or xylene and the following process of antigen retrieval.
Because of our unsatisfactory results with the previously described protocols, in this paper we have presented an alternative method which works well and reproducibly with the tissue specimen and antibodies we need for our investigation.

\section{References}

Bräsen JH, Kivela A, Röser K, Rissanen TT, Niemi M, Luft FC, et al. Angiogenesis, vascular endothelial growth factor and platelet-derived growth factor-BB expression, iron deposition, and oxidation-specific epitopes in stented human coronary arteies. Arterioscler Thromb Vasc Biol 2001;21:1720-6.

Frid MG, Shekhonin BV, Koteliansky VE, Glukhova MA. Phenotypic changes of human smooth muscle cells during development: late expression of heavy caldesmon and calponin. Dev Biol 1992;153:185-93.

Johansson B, Eriksson A, Thornell LE. Intermediate filament proteins in developing human arteries. Anat Embryol 1999;199:225-31.

Rammelt S, Corbeil D, Manthey S, Zwipp H, Hanisch U. Immunohistochemical in situ characterization of orthopedic implants on polymethyl methacrylate embedded cutting and grinding sections. J Biomed Mater Res 2007;83A:313-22.

Yoshida T, Owens GK. Molecular determinants of vascular smooth muscle cell diversity. Circ Res 2005;96:280-91. 


\title{
Clinical, echocardiographic and histopathologic findings in nine patients with surgically explanted ASD/PFO devices: Do we know enough about the healing process in humans?
}

\author{
Manfred Otto Vogt ${ }^{\mathrm{a}, *, 1}$, Andreas Kühn ${ }^{\mathrm{a}, 1}$, Jürgen Hörer ${ }^{\mathrm{b}}$, Christian Schreiber ${ }^{\mathrm{b}}$, Heike Schneider ${ }^{\mathrm{c}}$, \\ Rudi Foth ${ }^{\mathrm{c}}$, Andreas Eicken ${ }^{\mathrm{a}}$, John Hess ${ }^{\mathrm{a}}$, Matthias Sigler ${ }^{\mathrm{c}}$ \\ a Department of Pediatric Cardiology and Congenital Heart Disease, German Heart Center Munich, Technical University, Lazarettstr. 36, D-80636 Munich, Germany \\ ${ }^{\mathrm{b}}$ Department of Cardiovascular Surgery, German Heart Center Munich, Technical University, Lazarettstr. 36, D-80636 Munich, Germany \\ c Department of Pediatric Cardiology and Pediatric Intensive Care Medicine, Georg-August University, D-37099 Goettingen, Germany
}

\section{A R T I C L E I N F O}

\section{Article history:}

Received 23 July 2009

Accepted 26 September 2009

Available online $\mathrm{xxxx}$

\section{Keywords:}

Heart septal defects

Echocardiography

Thrombus

Immunohistochemistry

Pathology

\begin{abstract}
A B S T R A C T
Background: Atrial septal defects (ASD) and persistent foramen ovale (PFO) are managed in increasing numbers by catheter interventions as an attractive alternative to surgery. Early complications have been described in clinical series whereas late complications are rare. No series are reported with clinical, echocardiographic and histological data.

Methods and results: We collected clinical, echocardiographic, and histolological data of nine patients with surgically explanted devices. Occlusion devices were explanted after a mean interval of $3.4 \pm 2.4$ years (range 0.9-8.3). Indications were recurrent thromboembolic events in five, residual shunt/dislocation in three, and growing mass on echocardiography despite oral anticoagulation in one patient. Two patients suffered potentially live threatening events due to coronary embolism. One of them had to be resuscitated due to ventricular fibrillation. Histologically, residues of superficial thrombus formation could be demonstrated in two of the devices. In another patient, hyperplastic tissue formation was related to a local inflammatory process but not to a thrombus as suspected by echocardiography.

Conclusion: Late complications after device implantation may occur up to 8 years after device implantation and may be potentially live threatening. Echocardiographic controls should be prolonged beyond the first year after implantation and every explanted device should be histologically worked up in an experienced center. Up to now, the mechanisms of late thrombogenesis are not fully understood.
\end{abstract}

Crown Copyright @ 2009 Published by Elsevier Ireland Ltd. All rights reserved.

\section{Introduction}

Over the past 20 years catheter interventional atrial septal defect closure has gained worldwide acceptance and several studies have shown that catheter interventions are as safe and efficacious as open heart surgical interventions [1]. Numerous studies have shown an association between the presence of a patent foramen ovale (PFO) and cryptogenic stroke [2,3]. Despite an ongoing discussion, recurrent paradoxical cerebral embolism in the presence of a PFO associated with an atrial septal aneurysm is an accepted indication for percutaneous closure with a device [4].

Several devices available nowadays for clinical use are reported with high success and low complication rates [5-7]. In two clinical series thrombus formation is associated with certain devices in the

\footnotetext{
* Corresponding author. Tel.: +49 891218 3012; fax: +49 8912183013

E-mail address: drvogt@dhm.mhn.de (M.O. Vogt).

${ }^{1}$ Contributed equally.
}

early post-implant period $[8,9]$. In a case report, late bacterial endocarditis is discussed as a result of incomplete endothelialization [10].

The knowledge of a normal tissue reaction against the device is most often based on animal studies for premarket approval [11-14]. All these animal studies are based on relatively short follow-up periods [15] and there are only very limited data on the process of healing after device implantation in human beings [16]. Preliminary data on neoendothelialization have been published in a histopathological series [15] and in a case report [17] but without relevant clinical information.

We therefore report a series of 9 patients after surgical device explantation with detailed information on clinical course, echocardiographic follow-up and histopathological data which to our knowledge is unique in literature.

\section{Patients and methods}

2.1. Patients

Nine patients could be included in the study. The implantation procedure had been performed in three different centers. Surgically device explantation at a single center (German Heart Center Munich, Germany) and extended histological and immunohistological 
work-up following a predefined protocol at another single center (Georg-August University of Goettingen, Germany). Patients' history was taken from medical reports and all available transesophageal echocardiographic examinations were reevaluated by two independent examiners (VM and $\mathrm{KA}$ ).

\subsection{Echocardiography}

Follow-up transesophageal echocardiography focused on position and configuration of the device, proof or exclusion of residual shunts by means of color coded and contrast echocardiography under the valsalva maneuver and description of abnormal tissue on or around the device.

\subsection{Tissue preparation}

After surgical removal and flushing with normal saline, the tissue specimen containing the occluder was placed in formalin for fixation. The specimen was embedded in a synthetic resin (methylmethacrylate, Technovit 9100, KULZER \& Co, Wehrheim, Germany), hardened, and subsequently sectioned in slices of $0.8 \mathrm{~mm}$ using a diamond cutter ( 300 CP, Exakt GmbH, Norderstedt, Germany). These slices were ground down to $10-30 \mu \mathrm{m}$ using a rotational grinder $(400 \mathrm{CS}$, Exakt $\mathrm{GmbH}$, Norderstedt, Germany). Standard staining was performed with Richardson blue. For immunohistochemical staining, binding of first antibodies was detected using horseradish peroxidase conjugated secondary antibodies. The sections were counterstained with hemalaun.

Informed consent was obtained in all patients and all data were treated according to the 1975 declaration of Helsinki.

\section{Results}

\subsection{Clinical course}

Mean patient age at implantation was $35.5 \pm 13.5$ years (range: 19.1-55.9). Device implantation was due to significant left to right shunt on atrial level in three patients and due to cerebral embolism in combination with a PFO in six patients. In all six patients clinically relevant coagulopathy could be ruled out before the interventional closure. Clinical data of all patients are summarized in Table 1.

After a mean interval of $3.4 \pm 2.4$ years (range $0.9-8.3$ ) the devices had been explanted surgically. Indications for the surgical intervention were: recurrent left sided embolism (coronary and/or cerebral) in combination with a left and/or right sided thrombus in five patients, strut fractures in combination with dislocation, residual shunt or thrombotic formation in two patients, and dislocation with significant residual shunt in one and perforation of interatrial septum caused by a device strut in another patient.

In the group with recurrent thromboembolic events cranial imaging (MRI/CT) revealed more than one new embolic event after implantation of the device in each patient. In all of them except patient number $3 \mathrm{a}$ thrombotic formation on or around the device could be demonstrated on TEE as the most obvious reason for embolism (Figs. 1 and 2). Clinical data of patients with recurrent embolic events are summarized in Table 2.

There was a wide range in the time to first thromboembolic event after device implantation from 0.4 years to 7.8 years. In two of the 5 patients coronary embolism could be proven by late enhancement in more than one segment of the left ventricle and a normal coronary angiogram. Patient 9 presented with ventricular fibrillation as a first symptom of coronary embolism and regional wall motion abnormalities in the LV 2.3 years after ASD occlusion. At the same time a left sided thrombus at the central portion of the Amplatzer ASD occluder could be visualized on TEE and also on the right central portion (Fig. 1A). Due to immediate cardiac resuscitation with electrical cardioversion the patient survived. The same patient has had a first asymptomatic thrombus at the same localization (central left sided pin) 5 months after initial device implantation. He was put on oral anticoagulation with warfarin at that time for 6 months followed by 6 months of antiplatelet therapy with aspirin $100 \mathrm{mg} / \mathrm{day}$. The thrombus could no longer be seen on follow-up TEE two months after the initiation of oral anticoagulation and also 3 months after termination of antiplatelet therapy.

The second patient with suspected coronary embolism (patient 1 , Fig. 1B) did not show cardiac symptoms. He presented with embolic occlusion of a retinal artery and suffered another stroke with global

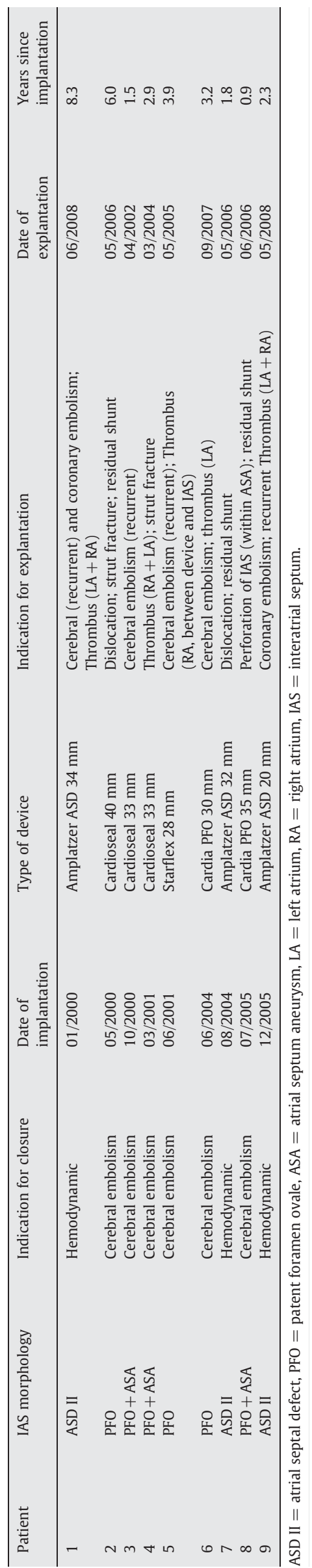




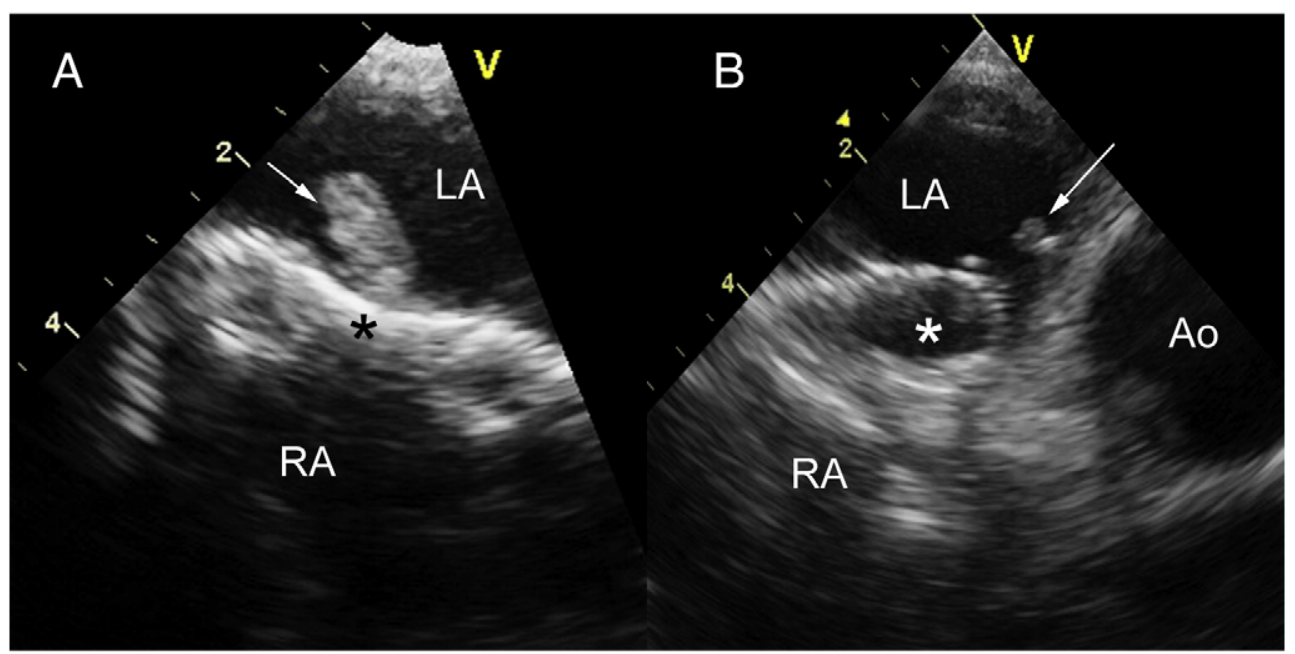

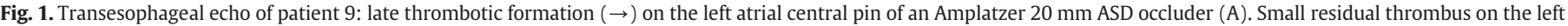
atrial roof of a bulgy $34 \mathrm{~mm}$ Amplatzer ASD occluder in patient 1 (B). *Marks Amplatzer device.

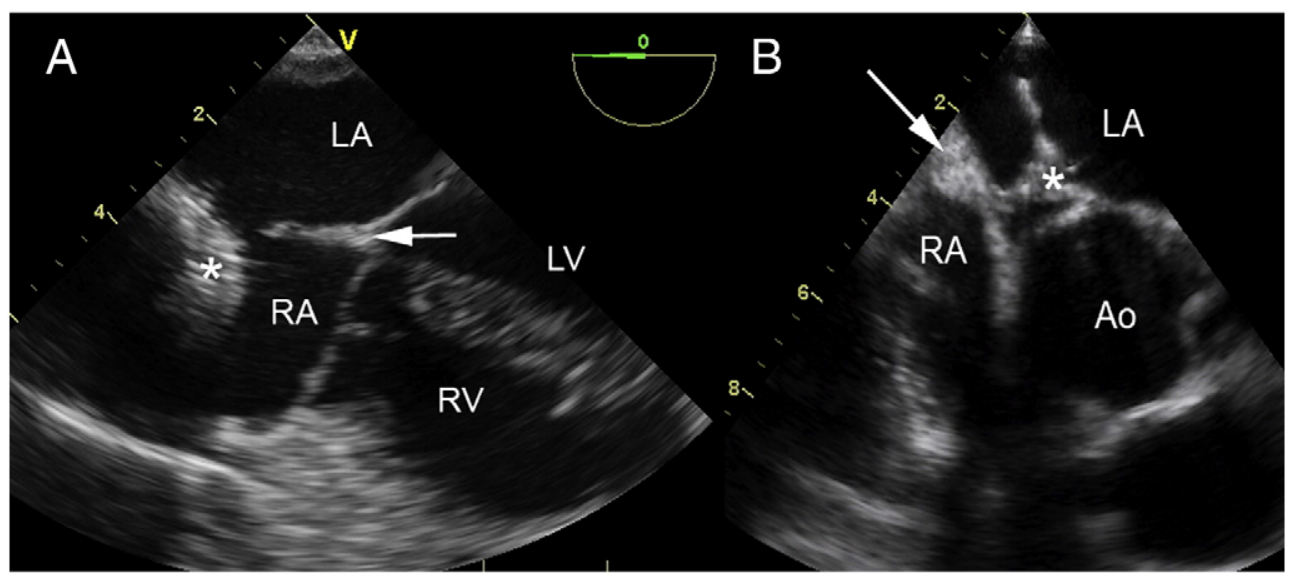

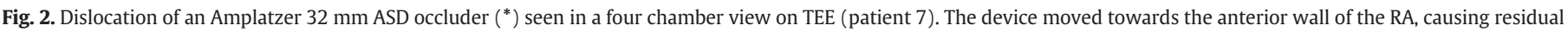

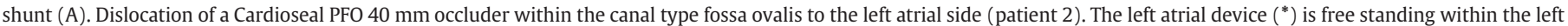
atrium, the right sided legs are pulled into the canal (B). $\rightarrow$ Marks the axis of the interatrial septum.

aphasia 4 days later. Thrombolytic therapy with recombinant tissue plaminogen activator (Actilyse, Boeringer Ingelheim, Germany) led to a complete resolution of the occluded cerebral media artery. As the most evident source of embolism a left sided thrombus formation on the device and on the ipsilateral wall of the left atrium could be demonstrated on TEE. The left atrial disc of the device showed an abnormal "mushroom like" configuration (Figs. 3 and 4).

\subsection{Echocardiographic follow-up}

All patients had had at least one follow-up TEE at the beginning of new symptoms after the intervention. Echocardiographic features are

Table 2

Patients with recurrent thrombembolic event after ASD/PFO occlussion.

\begin{tabular}{lllll}
\hline $\begin{array}{c}\text { Patient First thrombembolic } \\
\text { event (years after } \\
\text { intervention) }\end{array}$ & $\begin{array}{l}\text { Anticoagulation } \\
\text { at that time }\end{array}$ & $\begin{array}{l}\text { Number of } \\
\text { thrombembolic } \\
\text { events after } \\
\text { ASD/PFO closure }\end{array}$ & $\begin{array}{l}\text { First thrombus } \\
\text { detection } \\
\text { (years after } \\
\text { intervention) }\end{array}$ \\
\hline 1 & 7.8 & None & 2 & 8.2 \\
3 & 0.9 & None & 2 & No thrombus \\
5 & 0.4 & ASS (100 mg) & 3 & 0.4 \\
6 & 3.0 & None & 1 & 3.0 \\
9 & 2.3 & None & 1 & 0.5 \\
\hline
\end{tabular}

summarized in Table 3. Three of the nine patients had dislocation of the devices: 2 Cardioseal devices were dislocated within a tunnel like PFO, one Amplatzer ASD occluder initially had a small residual shunt but showed progressive dislocation towards the right atrium with subsequently significant residual shunt (Fig. 2A, B). One patient with a Cardia PFO occluder had a new device related perforation of his atrial septal aneurysm with left to right shunt. Due to his history of stroke he opted for the surgical option to avoid medical therapy like oral anticoagulation or antiplatelet therapy (patient number 8).

Five patients presented with novel tissue formation on or around the device. On TEE examination this was interpreted as thrombus formation. Four of the five patients presented with thromboembolic events, one patient (patient 4) was asymptomatic but due to progressive echogenic formation on the left and right atrial side despite effective oral anticoagulation surgery was indicated. Those patients with visible thrombus formations were put on intravenous heparin before surgery.

\subsection{Pathology}

Histopathological findings are briefly summarized in Table 4.

Macroscopically, 7 of the 9 occlusion devices showed abnormal findings. The bulgy protrusion of a left atrial retention disc of an Amplatzer ASD occluder (patient 1; Figs. 3 and 4A) was associated 


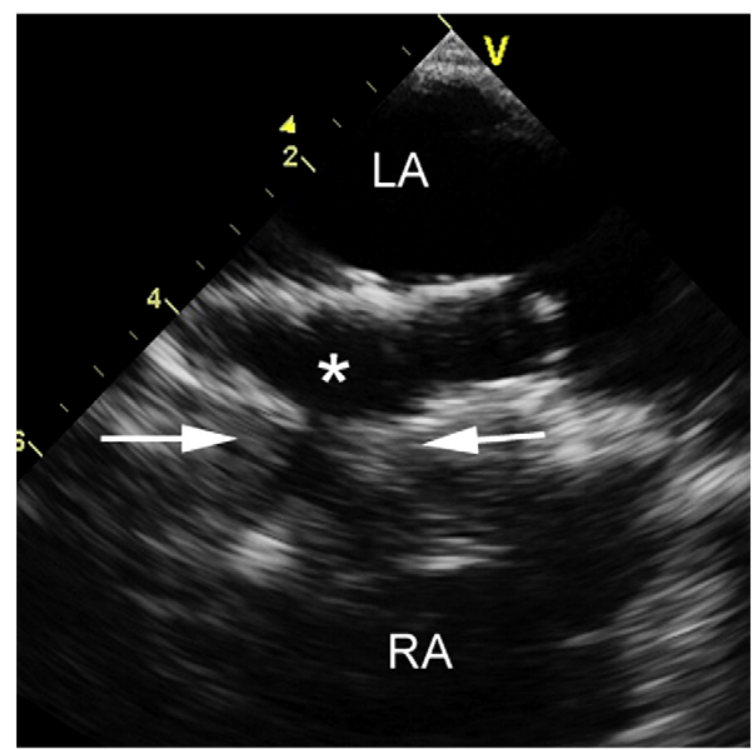

Fig. 3. Abnormal echo configuration of a $34 \mathrm{~mm}$ Amplatzer ASD occluder 8.24 years after implantation. The left atrial disc $\left({ }^{*}\right)$ is protruding like a mushroom into the left atrium (Patient 1, see also Fig. 4A).

with small pedunculate superficial thrombi as confirmed by histology (Fig. 5C). In another Amplatzer ASD occluder, clinical and echocardiographic suspicion of superficial thrombus formation correlated with the histological image of "spreading" of thrombotic material on the LA tissue surface next to the central pin (patient 9; Fig. 5D).
Table 3

Echocardiographic features.

\begin{tabular}{|c|c|c|c|c|}
\hline Patient & Position & Configuration & $\begin{array}{l}\text { Residual } \\
\text { shunt }\end{array}$ & Abnormal tissue \\
\hline 1 & Correct & $\begin{array}{l}\text { Inadequate deployment } \\
\text { of LA disc }\end{array}$ & No & $\begin{array}{l}\text { Thrombus on LA and } \\
\text { RA disc and LA wall }\end{array}$ \\
\hline 2 & $\begin{array}{l}\text { Dislocation } \\
\text { towards LA }\end{array}$ & $\begin{array}{l}\text { Dehiscence between } \\
\text { LA and RA umbrella }\end{array}$ & Yes & No \\
\hline 3 & Correct & $\begin{array}{l}\text { Abnormal position } \\
\text { of one strut in LA } \\
\text { ( } 8 \mathrm{~mm} \text { Distance } \\
\text { to IAS) }\end{array}$ & No & No \\
\hline 4 & $\begin{array}{l}\text { Dislocation } \\
\text { towards RA }\end{array}$ & $\begin{array}{l}\text { Dehiscence between } \\
\text { LA and RA umbrella }\end{array}$ & No & $\begin{array}{l}\text { Echogenic material } \\
\text { posterior-inferior } \\
\text { between RA and LA } \\
\text { umbrella and IAS }\end{array}$ \\
\hline 5 & Correct & $\begin{array}{l}\text { Dehiscence between } \\
\text { RA umbrella and IAS }\end{array}$ & No & $\begin{array}{l}\text { Echogenic material } \\
\text { posterior between } \\
\text { RA umbrella and IAS }\end{array}$ \\
\hline 6 & Correct & Dehiscence of LA strut & No & Thrombus on LA disc \\
\hline 7 & $\begin{array}{l}\text { Dislocation } \\
\text { towards RA }\end{array}$ & Correct & $\begin{array}{l}\text { Significant } \\
\text { left to right } \\
\text { shunt }\end{array}$ & No \\
\hline 8 & Correct & $\begin{array}{l}\text { Perforation of IAS } \\
\text { within ASA through } \\
\text { one strut }\end{array}$ & Yes & No \\
\hline 9 & Correct & Correct & No & $\begin{array}{l}\text { Thrombus on LA } \\
\text { and RA disc }\end{array}$ \\
\hline
\end{tabular}

$\mathrm{LA}=$ left atrium, $\mathrm{RA}=$ right atrium, $\mathrm{IAS}=$ interatrial septum, $\mathrm{ASA}=$ atrial septum aneurysm.

Two Cardioseal devices (patients 2 and 4) showed atypical deformation with protuberance of parts of the device into both atrial cavities (Fig. 4B, C). In both cases, the polyester fabric of the umbrellas appeared somehow retracted towards the metal arms of the device scaffold. In one Starflex device with regular configuration of the fabric,

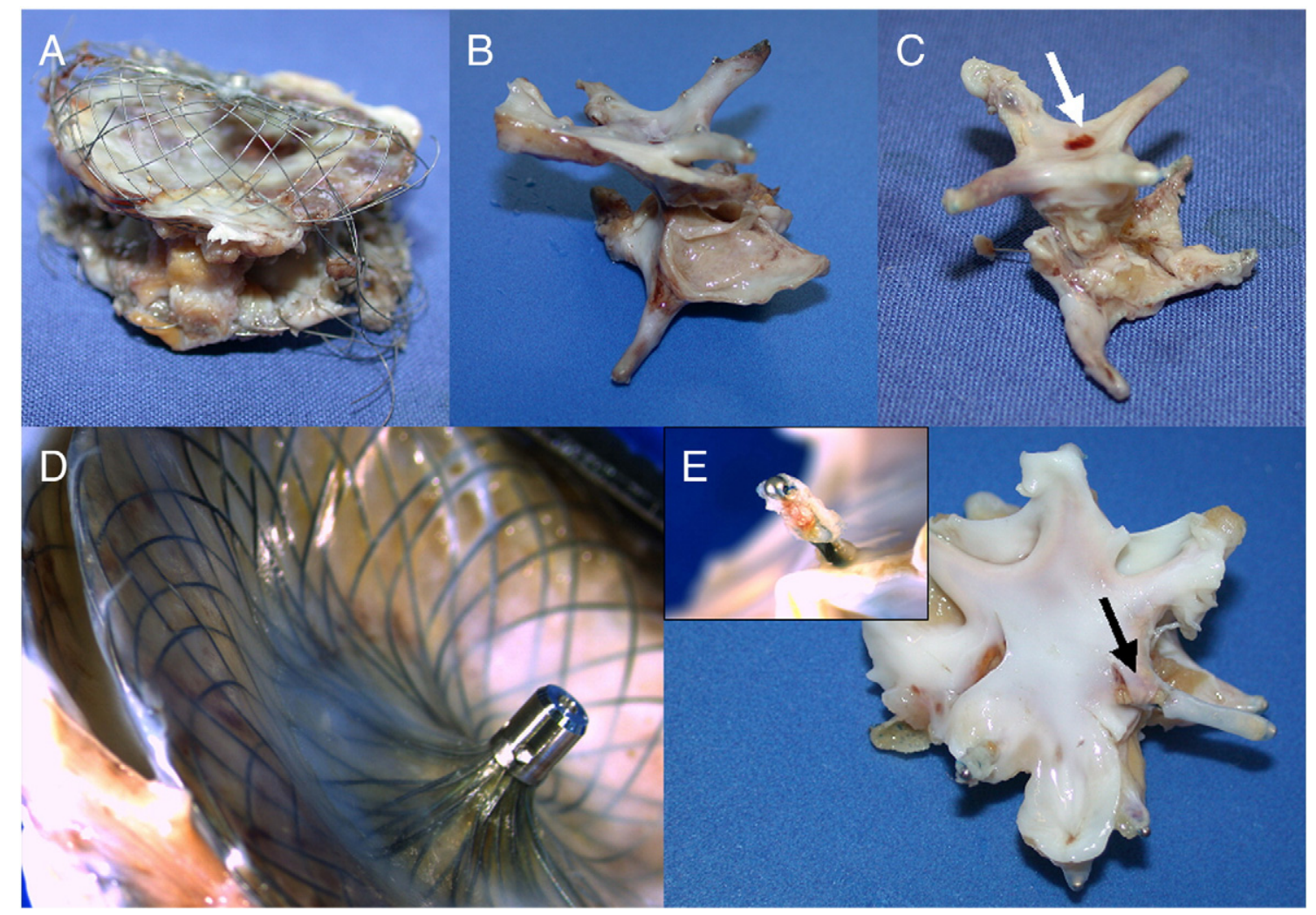

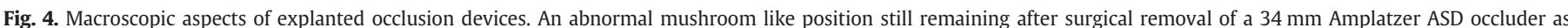

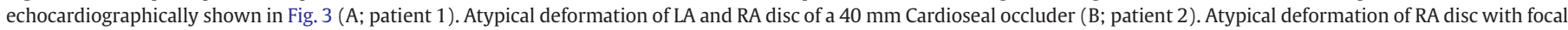

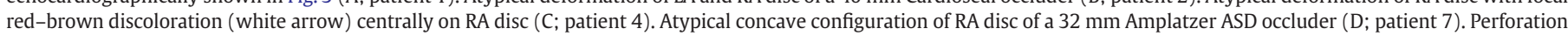
of one strut of RA disc of a Cardia 35 mm PFO-occluder through IAS (black arrow and detail) into LA (E; patient 8). 
Table 4

Histopathologic findings.

\begin{tabular}{|c|c|c|c|c|c|}
\hline \multirow[t]{2}{*}{ Patient } & \multirow[t]{2}{*}{$\begin{array}{l}\text { Macroscopic } \\
\text { aspect }\end{array}$} & \multirow[t]{2}{*}{$\begin{array}{l}\text { Surface/ } \\
\text { thrombus }\end{array}$} & \multirow[t]{2}{*}{ Tissue formation } & \multicolumn{2}{|l|}{$\begin{array}{l}\text { Inflammatory } \\
\text { reaction }\end{array}$} \\
\hline & & & & Lymphocytic & FBR \\
\hline 1 & $\begin{array}{l}\text { Atypical } \\
\text { deformation with } \\
\text { bulgy protrusion } \\
\text { of LA disc wires }\end{array}$ & $\begin{array}{l}\text { Superficial } \\
\text { thrombi (LA } \\
\text { and RA) }\end{array}$ & $\begin{array}{l}\text { Regular ingrowth } \\
\text { of implant }\end{array}$ & $(+)$ & $\begin{array}{l}+ \\
+\end{array}$ \\
\hline 2 & $\begin{array}{l}\text { Atypical } \\
\text { deformation of LA } \\
\text { and RA disc }\end{array}$ & $\begin{array}{l}\text { Regular neo- } \\
\text { endothelium }\end{array}$ & $\begin{array}{l}\text { Regular ingrowth } \\
\text { of implant }\end{array}$ & + & + \\
\hline 3 & $\begin{array}{l}\text { Without } \\
\text { pathological } \\
\text { findings }\end{array}$ & $\begin{array}{l}\text { Regular neo- } \\
\text { endothelium }\end{array}$ & $\begin{array}{l}\text { Regular ingrowth } \\
\text { of implant }\end{array}$ & + & $\begin{array}{l}+ \\
+\end{array}$ \\
\hline 4 & $\begin{array}{l}\text { Atypical } \\
\text { deformation of } \\
\text { RA disc; focal } \\
\text { red-brown } \\
\text { discoloration } \\
\text { centrally on RA } \\
\text { disc }\end{array}$ & $\begin{array}{l}\text { Superficial } \\
\text { hemorrhage } \\
\text { (RA) }\end{array}$ & $\begin{array}{l}\text { Regular ingrowth } \\
\text { of implant }\end{array}$ & + & $\begin{array}{l}+ \\
+\end{array}$ \\
\hline 5 & $\begin{array}{l}\text { Hyperplastic } \\
\text { tissue on RA disc }\end{array}$ & $\begin{array}{l}\text { Regular neo- } \\
\text { endothelium }\end{array}$ & $\begin{array}{l}\text { Regular ingrowth } \\
\text { of implant, } \\
\text { accumulation of } \\
\text { proteoglycane- } \\
\text { rich connective } \\
\text { tissue (RA) }\end{array}$ & +++ & $\begin{array}{l}+ \\
+\end{array}$ \\
\hline 6 & $\begin{array}{l}\text { Without } \\
\text { pathological } \\
\text { findings }\end{array}$ & $\begin{array}{l}\text { Regular neo- } \\
\text { endothelium }\end{array}$ & $\begin{array}{l}\text { Regular ingrowth } \\
\text { of implant }\end{array}$ & + & $\begin{array}{l}+ \\
+\end{array}$ \\
\hline 7 & $\begin{array}{l}\text { Atypical } \\
\text { deformation of } \\
\text { RA disc }\end{array}$ & $\begin{array}{l}\text { Regular neo- } \\
\text { endothelium }\end{array}$ & $\begin{array}{l}\text { Regular ingrowth } \\
\text { of implant }\end{array}$ & + & $\begin{array}{l}+ \\
+\end{array}$ \\
\hline 8 & $\begin{array}{l}\text { Perforation of one } \\
\text { strut of RA disc } \\
\text { through IAS into } \\
\text { LA }\end{array}$ & $\begin{array}{l}\text { Regular neo- } \\
\text { endothelium }\end{array}$ & $\begin{array}{l}\text { Regular ingrowth } \\
\text { of implant }\end{array}$ & + & $\begin{array}{l}+ \\
+\end{array}$ \\
\hline 9 & $\begin{array}{l}\text { Focal red-brown } \\
\text { discoloration } \\
\text { centrally on LA } \\
\text { disc }\end{array}$ & $\begin{array}{l}\text { Superficial } \\
\text { thrombus } \\
\text { (LA) }\end{array}$ & $\begin{array}{l}\text { Regular ingrowth } \\
\text { of implant }\end{array}$ & $(+)$ & $\begin{array}{l}+ \\
+\end{array}$ \\
\hline
\end{tabular}

$\overline{\mathrm{LA}}=$ left atrium, $\mathrm{RA}=$ right atrium, IAS $=$ interatrial septum, $\mathrm{FBR}=$ Foreign body reaction.

atypical hyperplastic tissue was seen on the surface of the right atrial umbrella (patient 5; Fig. 5A). This hyperplastic tissue was locally related to a massive lymphocytic infiltration locally related to the polyester material of the umbrella (Fig. 5A). In contrast, tissue hyperplasia was not associated with pronounced inflammatory reactions in patient 4 . In both devices, echocardiography prior to explantation had raised suspicion for thrombus formation which was not confirmed by histopathology.

The right atrial retention disc of another Amplatzer occluder (patient 7) showed a concave configuration in terms of an inwardcurving surface (Fig. 4D). The latter was not associated with abnormal histological findings. In one Cardia PFO occluder (patient 8), perforation of one of the right atrial disc struts into the left atrium could be confirmed macroscopically (Fig. 4E).

On histological evaluation, the principle finding of the newly formed tissue around the devices was proliferation of proteoglycanerich connective tissue with incorporated fibromuscular cells and neovascularization concordantly in all specimens. The extent of formation of this type of tissue varied considerably among the specimen. Patients 4 and 5 for example showed atypically large amounts of it without any evidence for thrombotic material as suspected by means of echocardiography.

Mild lymphocytic infiltrations were found throughout the specimen in a loose distribution pattern. The only exception was the device of patient 5 with a massive lymphocytic infiltration locally related the polyester fabric. The only other form of inflammation seen in our series was moderate foreign body reaction adjacent to the polyester material (Fig. 5B).

All explants showed the typical aspect of neoendothelialization as confirmed by immunostaining with antibodies against von Willebrand factor (Fig. 6). Superficial thrombus adherence was seen in two devices (patient 1 and 9; Fig. 5C and D). In another patient, focal red-brown discoloration of the RA disc surface could be histologically identified as superficial hemorrhage (patient 4).

\section{Discussion}

The indications for surgical explantation of ASD/PFO occlusion devices are not yet clarified. Recurrent thromboembolic events, residual shunting alone or in combination with dislocation of the device, and growing thrombus formation on the device despite adequate oral anticoagulation were the main indications in our series - comparable to those indications reported in literature [18]. However, in a more detailed case analysis in our series there are two of the five patients with recurrent thromboembolic events that cause deep concern from a clinical point of view: both of them had coronary and also cerebral embolism during follow-up.

The first patient had his first symptoms 7.8 years after implantation of a $34 \mathrm{~mm}$ Amplatzer ASD occluder. On TEE his left atrial disc had a bulgy mushroom like configuration possibly caused by an oversized stent of the device. Histological examination confirmed superficial thrombi on left and right atrial surface of the device. Oversized Amplatzer ASD occluder does not flatten in the follow-up as it is described in literature [19].

Thrombus formation after transcatheter occlusion is reported to be a problem of the early interval after implantation ( $<6$ months). Early thrombi were interpreted as a result of missing endothelialization and some groups therefore started antiplatelet therapy the day before the implantation [9]. The incidence of thrombus formation (1.2 to $17.5 \%$ ) also seems to be highly related to the design and type of the device $[8,9,20,21]$. Whereas in the largest follow-up series dealing with that problem [8], the Amplatzer ASD/PFO occluder was the only type of device with no thrombus formation in the early follow-up, supported also by data from smaller series [22]. In contrast, others have shown early [9] and also late thrombus formation for Amplatzer occluder as well [23], the longest interval being 5 years after implantation [24]. Our patient with an interval of more than 8 years after implantation poses new questions: despite a regular ingrowth of the implant on histology thrombotic formation grew on both sides of the device with symptomatic recurrent coronary, cerebral and ocular embolism. No cardiac or extracardiac reason could be found, so that the reason for thrombus formation in this case remains unclear.

The clinical case of patient 9 also poses questions. His first thrombus formation could be demonstrated 5 months after implantation of an Amplatzer $20 \mathrm{~mm}$ ASD occluder and 10 days after discontinuation of aspirin therapy. After 6 months of oral anticoagulation and complete resolution of the thrombus he was put on aspirin $100 \mathrm{mg}$ for 6 more months. 2.3 years after the implantation he presented with ventricular fibrillation. After successful resuscitation thrombotic material could be seen echocardiographically on the same location - central pin of LA disc - as initially and coronary embolism could be demonstrated on cardiac MRI with positive late enhancement and no sign of other coronary pathology on coronary angiography.

His first episode of early thrombosis may be explained by incomplete endothelialization and there might be a context with the discontinuation of Aspirin 10 days before. But after surgical removal of the device the bar metal left atrial central pin did not show any endothelialization visually and histologically. As we have seen the same localization of thrombus formation in three more patients with Amplatzer devices we cannot exclude that the central bar metal pin especially on the left disc plays a direct or indirect role in the genesis of thrombus formation in that type of device. 


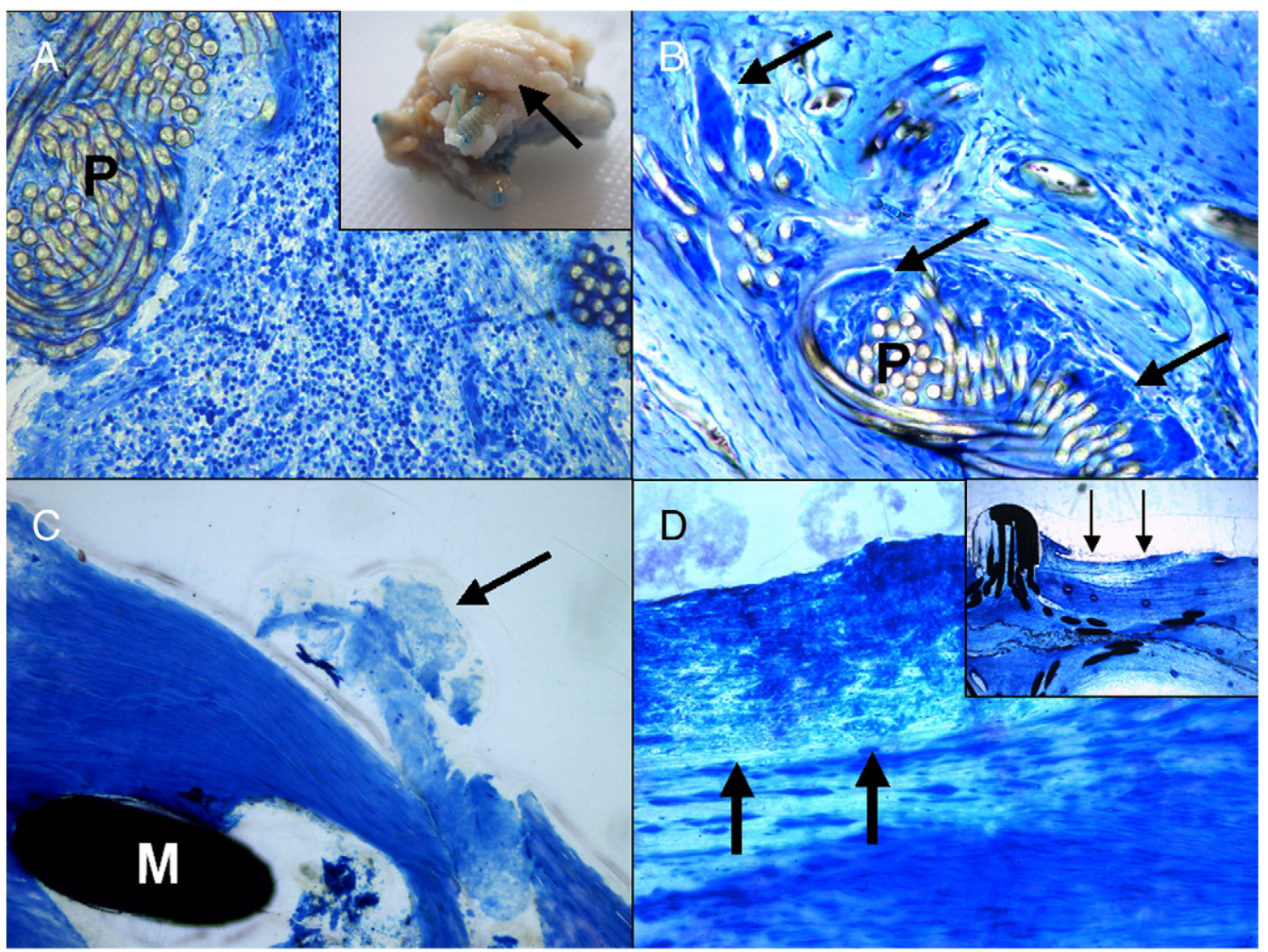

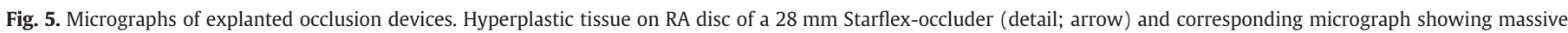

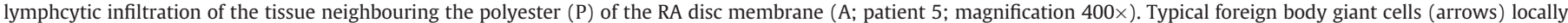

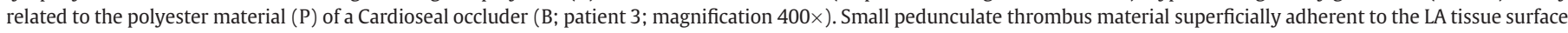

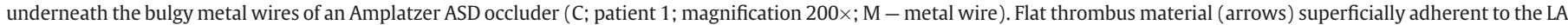
tissue surface next to the central pin (detail) of an Amplatzer ASD occluder (D; patient 9; magnification 200×).

As this young patient (an amateur soccer player) could be successfully resuscitated through immediate electric cardioversion by a physician during a soccer match, the mechanism of ventricular fibrillation induced by cardiac embolism may play a role in clinically unexplained late death after ASD device implantation as also described in other series [9].

Patient 4 with a Cardioseal $33 \mathrm{~mm}$ device showed progressive tissue growth between device and atrial septum, beginning on the right side and later also on the left atrial side of the device despite adequate oral

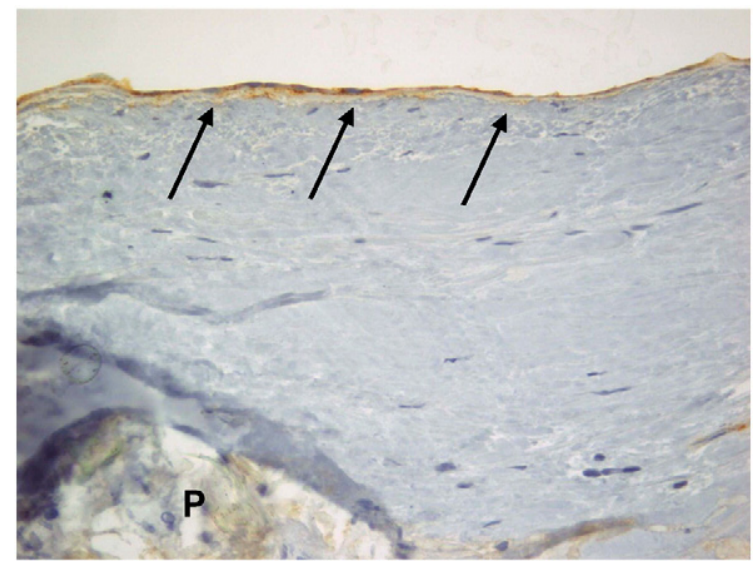

Fig. 6. Immunohistochemical staining (antibodies against von Willebrand factor) demonstrating superficial endothelial cell coverage of a Cardioseal occluder (patient 4; magnification $400 \times$ ). anticoagulation. As on echocardiography it is not possible to define the true nature of this tissue, the device was explanted. Histology showed large amounts of proteoglycane-rich connective tissue with incorporated fibromuscular cells, but no thrombus formation and no atypical inflammatory reaction as it was found for patient 5 regarding the superficially formed hyperplastic tissue. The mechanism leading to local inflammation as one possible cause for tissue hyperplasia in patient 4 remains unclear since this patient showed no signs of systemic inflammation.

Data on biological responses to vascular occlusion devices after implantation are sparse. However, most aspects of the nine devices examined in this study are concordant with those that have been described before $[15,16]$. There has been no study correlating clinical, echocardiographic, and histopathological data. In fact, this is the first time that superficial thrombus formation could be demonstrated by means of histopathology. As shown and as supposed by others before, protruding material on the left atrial side such as the central pin of the Amplatzer occlusion device seems to be especially prone to thrombus formation. The magnitude of the problem of late thrombogenesis is not known up to now as data on longterm follow-up of these patients do not exist.

\section{Conclusion}

In our series late complications after device implantation occurred up to 8 years after implantation. Two of nine patients suffered potentially live threatening events. These facts demonstrate the necessity of a cardiologic follow-up of those patients beyond the first year after implantation. As many of the mechanisms of late thrombus 
formation are not at all understood, all surgically explanted devices should be worked up histologically in experienced centers. Nationwide data bases with collections of clinical data of all implanted occlusion devices and patients follow-up would help to get more and reliable information on the true incidence especially of late complications.

\section{Acknowledgements}

The authors thank Andrea Poppe and Karin Baer for technical assistance.

The authors of this manuscript have certified that they comply with the Principles of Ethical Publishing in the International Journal of Cardiology [25].

\section{References}

[1] Cowley CG, Lloyd TR, Bove EL, Gaffney D, Dietrich M, Rocchini AP. Comparison of results of closure of secundum atrial septal defect by surgery versus Amplatzer septal occluder. Am J Cardiol 2001;88(5):589-91.

[2] Handke M, Harloff A, Olschewski M, Hetzel A, Geibel A. Patent foramen ovale and cryptogenic stroke in older patients. N Engl J Med 2007;357(22):2262-8.

[3] Mas JL, Arquizan C, Lamy C, et al. Patent Foramen Ovale and Atrial Septal Aneurysm Study Group. Recurrent cerebrovascular events associated with patent foramen ovale, atrial septal aneurysm, or both. N Engl J Med 2001;345(24):1740-6.

[4] Meier B, Lock JE. Contemporary management of patent foramen ovale. Circulation 2003:107(1):5-9.

[5] Chan KC, Godman MJ, Walsh K, Wilson N, Redington A, Gibbs JL. Transcatheter closure of atrial septal defect and interatrial communications with a new self expanding nitinol double disc device (Amplatzer septal occluder): multicentre UK experience. Heart 1999;82(3):300-6.

[6] Hausdorf G, Kaulitz R, Paul T, Carminati M, Lock J. Transcatheter closure of atrial septal defect with a new flexible, self-centering device (the STARFlex Occluder). Am J Cardiol 1999;84(9):1113-6.

[7] Du ZD, Hijazi ZM, Kleinman CS, Silverman NH, Larntz K. Comparison between transcatheter and surgical closure of secundum atrial septal defect in children and adults: results of a multicenter nonrandomized trial. J Am Coll Cardiol 2002;39 (11):1836-44.

[8] Krumsdorf U, Ostermayer S, Billinger K, et al. Incidence and clinical course of thrombus formation on atrial septal defect and patient foramen ovale closure devices in 1,000 consecutive patients. J Am Coll Cardiol 2004;43(2):302-9.
[9] Chessa M, Carminati M, Butera G, et al. Early and late complications associated with transcatheter occlusion of secundum atrial septal defect. J Am Coll Cardiol 2002;39(6):1061-5

[10] Slesnick TC, Nugent AW, Fraser Jr CD, Cannon BC. Images in cardiovascular medicine. Incomplete endothelialization and late development of acute bacterial endocarditis after implantation of an Amplatzer septal occluder device. Circulation 2008;117(18):e326-7.

[11] Bloch Thomsen A, Schneider M, Baandrup U, et al. Animal experimental implantation of an atrial septal defect occluder system. Heart 1998;80(6):606-11.

[12] Lock JE, Rome JJ, Davis R, et al. Transcatheter closure of atrial septal defects. Experimental studies. Circulation 1989;79:1091-9.

[13] Kuhn MA, Latson LA, Cheatham JP, et al. Biological response to Bard Clamshell Septal Occluders in the canine heart. Circulation 1996;93(7):1459-63.

[14] Sharafuddin MJ, Gu X, Titus JL, Urness M, Cervera-Ceballos JJ, Amplatz K. Transvenous closure of secundum atrial septal defects: preliminary results with a new selfexpanding nitinol prosthesis in a swine model. Circulation 1997;95(8):2162-8.

[15] Sigler M, Jux C. Biocompatibility of septal defect closure devices. Heart 2007;93 (4):444-9.

[16] Kreutzer J, Ryan CA, Gauvreau K, Van Praagh R, Anderson JM, Jenkins KJ. Healing response to the Clamshell device for closure of intracardiac defects in humans. Catheter Cardiovasc Interv 2001;54(1):101-11.

[17] Sigler M, Kriebel T, Wilson N. Histological confirmation of complete endothelialisation of a surgically removed Amplatzer ASD occluder. Heart 2006;92(12):1723.

[18] Walther T, Binner C, Rastan A, et al. Surgical atrial septal defect closure after interventional occluder placement: incidence and outcome. J Thorac Cardiovasc Surg 2007;134(3):731-7.

[19] Cao QL, Du ZD, Joseph A, et al. Immediate and six-month results of the profile of the Amplatzer septal occluder as assessed by transesophageal echocardiography. Am J Cardiol 2001:88(7):754-9.

[20] La RK, Krause D, Becker M, Beuckelmann DJ, Deutsch HJ, Hopp HW. Transcatheter closure of atrial septal defects in adults. Practicality and safety of four different closure systems used in 102 patients. Dtsch Med Wochenschr 2001;126(38):1030-6.

[21] Gastmann O, Werner GS, Babic UU, Figulla HR. Thrombus formation on transcatheter ASD occluder device in a patient with coagulation factor XII deficiency. Cathet Cardiovasc Diagn 1998;43(1):81-3.

[22] Anzai $H$, Child J, Natterson B, et al. Incidence of thrombus formation on the CardioSEAL and the Amplatzer interatrial closure devices. Am J Cardiol 2004;93 (4):426-31.

[23] Egred M, Morrison L. A late complication of a patent foramen ovale Amplatzer occluder device. Eur Heart J 2006;27(13):1604.

[24] Stollberger C, Finsterer J, Krexner E, Schneider B. Stroke and peripheral embolism from an Amplatzer septal occluder 5 years after implantation. J Neurol 2008;255(8):1270-1 [Epub 2008 Jun 13].

[25] Coats AJ. Ethical authorship and publishing. Int J Cardiol 2009;131:149-50. 


\section{Danksagung}

Mein besonderer Dank gilt Herrn Priv.-Doz. Dr. med. M. Sigler für die Überlassung des Themas und insbesondere für die geduldige und persönliche Betreuung meiner Dissertation.

Ferner möchte ich Herrn Dr. rer. nat. Th. Quentin für die fachliche sowie Frau Poppe und Frau Bär für die praktische Unterstützung im Forschungslabor der Pädiatrischen Kardiologie danken.

Des Weiteren möchte ich mich bei Herrn Prof. Dr. med. Th. Paul für die Möglichkeit des wissenschaftlichen Arbeitens bedanken. 


\section{Lebenslauf}

Als drittes Kind meiner Eltern Richard und Alwine Foth wurde ich am 23.12.1974 in Bielefeld-Gadderbaum geboren. Von 1981 bis 1985 besuchte ich die Grundschule in Bielefeld und schloss 1991 die Sekundarstufe I mit dem Abschluss der Fachoberschulreife an der Vennhofschule ab. Von 1991 bis 1994 besuchte ich die Carl-Severing-Schulen und erlangte dort die allgemeine Hochschulreife.

In den Jahren 1994 bis 1996 leistete ich in der Kinderklinik des Evangelischen Krankenhauses in Bielefeld meinen Zivildienst. Anschließend studierte ich für ein Semester die Fächer Diplom-Biologie und DiplomPädagogik an der Universität in Bielefeld. Von 1997 bis 2000 befand ich mich in der Ausbildung zum Kinderkrankenpfleger und schloss diese erfolgreich ab. Anschließend nahm ich die Berufstätigkeit als Kinderkrankenpfleger auf und war bis 2007 im Herzzentrum Bad Oeynhausen angestellt. 2002 begann ich das Studium der Humanmedizin an der Georg-August-Universität in Göttingen und schloss dieses 2008 erfolgreich ab.

Seit dem 1.1.2009 bin ich in der Abteilung Pädiatrie III mit Schwerpunkt Pädiatrische Kardiologie und Intensivmedizin unter der Leitung von Herrn Prof. Dr. med. Th. Paul im Zentrum Kinderheilkunde und Jugendmedizin der Universität Göttingen als Assistenzarzt beschäftigt. 